Communication with Children and Adolescents about the Diagnosis of a Life Threatening Condition in their Parent

Louise Dalton", Elizabeth Rapa", Sue Ziebland, Tamsen Rochat, Brenda Kelly, Lucy Hanington, Ruth Bland, Aisha Yousafzai, Alan Stein*, Communication Expert Groupt

\title{
Authors
}

L Dalton DClinPsy. Department of Psychiatry, University of Oxford, Oxford, UK

E Rapa D.Phil. Department of Psychiatry, University of Oxford, Oxford, UK

Prof S Ziebland MSc. Nuffield Department of Primary Care Health Sciences, University of Oxford, Oxford, UK

T Rochat PhD. Department of Paediatrics, School of Clinical Medicine, Faculty of Health Sciences, University of Witwatersrand, Johannesburg, South Africa and Human Sciences Research Council, Johannesburg, South Africa

K Fredman Stein MSc. Department of Psychology, University of Bath, Bath, UK

B Kelly FRCOG. Nuffield Department of Women's and Reproductive Health, University of Oxford, Oxford, UK, and Oxford University Hospitals NHS Foundation Trust, Oxford, UK

L Hanington MRCPCH. Department of Psychiatry, University of Oxford, UK

R Bland MD. School of Public Health, Faculty of Health Sciences, University of Witwatersrand, Johannesburg, South Africa, and Institute of Health and Wellbeing, Glasgow, UK and Royal Hospital for Children, Glasgow, UK

A Yousafzai PhD. Harvard T H Chan School of Public health, Boston, Massachusetts, USA

Professor Alan Stein FRCPsych. Department of Psychiatry, University of Oxford, Oxford, UK and School of Public Health, Faculty of Health Sciences, University of Witwatersrand, Johannesburg, South Africa*

+ Members listed at the end of the paper

\# Joint first author

*Corresponding author: Prof Alan Stein, Department of Psychiatry, University of Oxford, OX3 7JX, UK alan.stein@psych.ox.ac.uk.01865618190 


\section{Communication with Children and Adolescents about the Diagnosis of a Life Threatening Condition in their Parent}

Many adults diagnosed with a life threatening condition have children living at home; they and their partners face the dual challenge of coping with the diagnosis while trying to maintain a parenting role. Parents are often uncertain about how, when and what to tell their children about the condition and are fearful of the impact on their family. There is evidence that children are often aware that something is seriously wrong and want honest information. Healthcare professionals play a key role in supporting and guiding parents and caregivers to communicate with their children about the diagnosis. However, the practical and emotional challenges of communicating with families are compounded by a lack of evidence-based guidelines.

This narrative review considers children's awareness and understanding of their parents' condition, the effect of communication around parental life threatening condition on their wellbeing, factors that influence communication and the challenges to achieving effective communication. Children's and parents' preferences about communication are outlined. An expert workshop was convened to generate principles for healthcare professionals, intended as practical guidance in the current absence of empirically-derived guidelines. 


\section{Communication with Children and Adolescents about the Diagnosis of a Life Threatening Condition in their Parent}

Introduction

Many adults diagnosed with a life threatening condition (LTC) are parents with children living at home. In the USA alone it is estimated that 2.85 million children (age 18 years or younger) are living with a parent who has been diagnosed with cancer. ${ }^{1}$ In low and middle income countries (LMICs) LTCs affect even more families; the World Health Organisation (WHO) estimates $70 \%$ of deaths from cancer worldwide occur in LMICs. ${ }^{2}$ Life threatening infections such as HIV are also more common in LMICs with sub-Saharan Africa the most severely affected; nearly 1 in every 25 adults (4.2\%) are living with HIV and in parts of Southern Africa over a quarter of pregnant women are HIV-positive. ${ }^{3}$ With Prevention of Mother to Child Transmission programmes, the vast majority of their children are HIVnegative but are born into families where at least one parent is HIV-positive. Although treatment advances for HIV have markedly improved long-term prognosis, daily medication and frequent clinic appointments are still required. Furthermore, over one million people died of HIV in 2016, largely due to lack of access to adequate treatment. ${ }^{4}$

Parental LTCs have an impact on the physical, social and emotional wellbeing of children. A large cohort study of over 60,000 children in Finland found significantly higher use of psychiatric services by children who had been affected by parental cancer before the age of 21 years. ${ }^{5}$ In low income settings, parental illness and/or death can even impact on child survival; in rural South Africa the risk of mortality for children under five increased both after their mother had died and in the months before her death. ${ }^{6}$ Parents with LTCs face the dual challenge of coping with their diagnosis and treatment, while simultaneously maintaining their caregiving role. Parents may feel unsure about how to talk to their child and how much information to share with them, while also wanting to protect their child from distress. Parents would benefit from clear guidance and support from healthcare professionals (HCPs) about how to approach these topics with their children. However, when a parent is ill, HCPs involved are primarily focussed on the adult patient. They may never have direct contact with the patient's children or be aware of the impact of the illness on the wider family. Indeed, many may be unsure about whether considering the needs of the patient's children forms part of their role. It can be difficult for HCPs treating adults to raise the issue of children's understanding of parental illness and the importance of communicating with them about the illness; this can deny parents much needed resources and support. Empirically based, parent/caregiver-focused recommendations are largely lacking, ${ }^{7}$ making this emotionally challenging task especially difficult for HCPs.

\section{Aim of the review}

Given the scale of the global burden of LTCs affecting parents, and the absence of evidence-based guidelines to support HCPs and families to communicate the diagnosis to children, the available literature was examined with the aim of addressing four main questions:

1) What is the evidence that communication with children about parental LTC is important? 
2a) What is the impact of communication on children and adolescents' emotional, behavioural and health outcomes? $2 \mathrm{~b}$ ) What is the impact of communication on parents and the wider family system?

3a) What factors influence the process of communication? 3b) What are the barriers and challenges to communication?

4) What are the reported preferences of children, adolescents and parents about the way diagnosis and information is conveyed?

The outcomes of the narrative review and previously published recommendations ${ }^{8}$ formed the basis of discussion at a workshop of international experts in 2017 to generate a framework of communication principles to address the lack of evidence based guidelines.

\section{Methods (see appendix)}

\section{Results}

\section{Findings of the review}

In HICs research has largely focused on the experience of children and parents with cancer. In contrast, issues around HIV/AIDS disclosure have dominated the research from LMICs. Practical and ethical considerations have influenced research methodology, with much of the work conducted through observational studies, qualitative interviews, retrospective self-report and intervention studies, rather than randomised controlled trials (RCTs). Most studies in HICs involve parents/caregivers and children, whereas those in LMICs are informed almost exclusively by parents/caregivers and rarely involve children directly. Furthermore most of the communication provided by HCPs is with the parent, in order to help them talk to their children, rather than with children directly.

Relevant articles are summarised in table 1, with table 2 detailing the intervention studies (see appendix).

\section{1) What is the evidence that communication with children about parental LTC is important?}

The literature identifies several compelling reasons to encourage parents, supported by HCPs, to discuss their illness openly with their children including:

i) children often have an awareness of changes to their parents' health even if they have not been formally told

Children are very observant and may notice their parents' physical deterioration and/or be aware their parent is taking medication or going to clinic. A Chinese quantitative survey of children ( $n=626 ; 6-$ 17yrs) found that only a minority (31-39\%) heard their parents' HIV status from the parents themselves, yet of those who were not told by their parents, $85-88 \%$ were aware of their parents' diagnosis or illness through their own observations or from other people. ${ }^{9}$ In Botswana ( $\left.n=32 ; 5-18 y r s\right)$ a third of HIV-positive parents thought that their child had guessed their HIV-positive status. ${ }^{10} \mathrm{~A}$ qualitative study in Zimbabwe ( $n=56$ orphans; 7-22yrs) found that many bereaved adolescents partially knew, or strongly suspected that their parents were HIV-positive although few had been formally told. ${ }^{11}$ Children often felt unable to ask about the changes they have noticed in their parents 
leading to tension and anxiety. ${ }^{12}$ A qualitative study ( $\left.n=28 ; 3-18 y r s\right)$ in the USA reported that even young children demonstrated an awareness of their parent's medical condition (e.g. a three-year-old drawing pictures of her mother with and without hair following chemotherapy) and its implications. ${ }^{13}$ A UK-based qualitative study of mothers with breast cancer $(n=37)$ and their children $(n=31 ; 6-18 y r s)$ found that some of the younger children (age 6 years) were aware of cancer as a LTC and had suspected something was seriously wrong before they were told the diagnosis. ${ }^{14}$

\section{ii) children often wish to know about their parents' illness}

Research consistently highlights the need for communication with children in a timely manner and the potential negative consequences when information is absent. A quantitative study in Sweden of young adults bereaved 6-9 years earlier during their adolescence ( $n=622 ; 13-16 y r s)$ found that $98 \%$ thought that teenage children should be informed when their parents' death was imminent, although only $59 \%$ had themselves been told. ${ }^{15} \mathrm{~A}$ qualitative study in the UK of adults $(n=33)$ who had experienced the death of a parent during childhood (13mths-17yrs), reported that their distress had been compounded by a lack of accurate information about their parent's death. ${ }^{16} \mathrm{~A}$ Danish qualitative study involving parents with cancer and their children ( $n=21$ children from 15 families; 8-15yrs), reported that with the benefit of hindsight, parents who had allowed some time to elapse before disclosing their diagnosis regretted this decision and felt that their children had reacted negatively to not being told earlier. ${ }^{17}$

iii) in the absence of information children can misinterpret parental symptoms and construct their own (mis)understanding, leaving them distressed and emotionally isolated

When children are not given information about their parent's illness, they attempt to make sense of the situation on their own. Children's beliefs can be "more dire than the truth" and it is essential to dispel misconceptions and "magical thinking"18,19 (see review of child LTC for developmental stages of children's understanding of illness and death). Clear communication can help children prepare for changes and/or loss enabling them to receive support. ${ }^{20} \mathrm{An}$ absence of information may result in:

a. misinterpretation of parental symptoms; hair loss and other side effects of treatment can be wrongly interpreted as deterioration in their parent's condition, and adequate explanation can provide reassurance. $^{21,22}$

b. children relying on their own observations to construct their reality; in an Ugandan study adolescents (13-19yrs) who were not told their parent had died of HIV/AIDS, attributed the death to either a treatable condition or a spiritual cause. ${ }^{23}$

c. children worrying that they have caused the illness. ${ }^{14,18,24}$ In a US study, children aged 7-11 years $(n=87)$ attempted to understand their parent's illness through links with unrelated events. ${ }^{18}$ Bereaved adolescents (13-18yrs) in another US study $(n=11)$ reported that insufficient or distorted information resulted in feelings of regret and guilt about their possible role in causing or failing to prevent the death. ${ }^{25}$

d. children worrying about their own health and risk of developing a similar condition. ${ }^{14,18,24}$

2a) What is the impact of communication on children and adolescents' emotional, behavioural and health outcomes? 
Research has explored the relationship between communication about a parent's illness and children's psychological symptoms, with many studies indicating the benefits of communication for children.

A longitudinal study in the USA assessed outcomes for HIV-positive mothers and their HIV-negative children ( $n=135 ; 6-11 y r s) .{ }^{12}$ During the study a number of mothers disclosed their HIV status to their children. Analyses indicated a trend towards lower anxiety and a significant decrease in symptoms of depression in the children following maternal disclosure. ${ }^{12}$ Children whose mothers disclosed their diagnosis also reported lower levels of negative self-esteem (child-reported) ${ }^{26}$ and lower levels of aggressiveness (maternal-report) ${ }^{12}$ compared with children of non-disclosing mothers.

Positive family relationships were associated with lower anxiety and depression in adolescents $(n=50$; 12-19yrs) whose parent had cancer in a USA study. ${ }^{27}$ The relationship between anxiety and family cohesion was mediated by the extent to which family members expressed their thoughts and feelings (adolescent-report). ${ }^{27}$ A quantitative study in the UK of adolescents ( $\left.n=56 ; 11-17 y r s\right)$ and their mothers with early stage breast cancer found adolescents had higher total problem scores, both internalising symptoms (anxiety/depression symptoms) and externalising behaviours, that were significantly associated with poor communication generally. ${ }^{28} \mathrm{~A}$ mixed methods study of children in Israel ( $n=44 ; 6-16 y r s)$ found that those who had been explicitly told the name of their parent's illness (cancer) and its serious nature had significantly lower levels of anxiety. ${ }^{29}$

A Dutch quantitative study of adolescents and young adults ( $n=284 ; 11-23 y r s)$ who had a parent with cancer found that daughters who perceived their parent's illness to be more serious had higher levels of stress, although this association was not found for sons. ${ }^{30}$ This study did not compare children's perceptions of seriousness to clinical ratings of disease severity, but concluded that it is important to ensure children's perceptions are accurate to minimise unnecessary anxiety. ${ }^{30}$

Research has also explored the relationship between communication and symptoms of post-traumatic stress disorder. Problems in communication with either an ill or a healthy parent (in families where one parent has cancer) were associated with greater symptoms of post-traumatic stress in adolescents ( $n=212 ; 11-18 y r s$ ) in the Netherlands. ${ }^{31}$ Issues such as an absence of sharing feelings or avoiding talking about particular topics with either their ill, or healthy parent, were significantly related to higher scores on the avoidance subscale and total distress on the Impact of Events Scale, for both sons and daughters. Sons also reported more intrusive and distressing thoughts when communication was problematic. ${ }^{31}$ Open communication (quality of exchanging information, freedom in communication, comprehension and satisfaction with communication) between daughters and their healthy parents was associated with fewer symptoms of intrusion, avoidance and total distress. ${ }^{31}$

While there are many studies supporting the value of talking with children about a parent's LTC, this is not universal. A quantitative study in the UK with children and adolescents ( $n=80 ; 8-16 y r s$ ) who had a parent with cancer found no association between measures of child adjustment (child-rated anxiety and maternal ratings of child behaviour) and communication. ${ }^{32}$ Similarly, a quantitative study in Greece of parents ( $n=101)$ and children ( $n=56 ; 4-17 y r s)$ in which one parent was affected by multiple sclerosis found no association between communication around illness and family functioning. ${ }^{33}$ However a South African study found that mothers $(n=103)$ disclosure of HIV diagnosis to their 
adolescents (11-16yrs) was associated with an increase in behavioural, but not emotional problems. ${ }^{34}$ Nonetheless the strongest predictors of behavioural problems were family factors, with fewer symptoms reported in children with better parent-child and inter-parental relationships. ${ }^{34}$

The relationship between psychological wellbeing and communication may be more nuanced over time. An observational study of the impact of HIV disclosure on adolescents ( $n=395 ; 11$-18yrs) in the USA found that problem behaviours (unprotected sex, alcohol use, drug use and contact with criminal justice system) were higher in adolescents who knew their parents HIV status at the time of recruitment to the study. ${ }^{35}$ However, there were significant differences in the trajectory over the following 5 years with problem behaviours decreasing over time among the disclosed children and increasing amongst the non-disclosed children. ${ }^{35}$

Research has examined the relationship between the amount of information given to children and psychological outcomes. The Greek study outlined above ( $n=56 ; 4-17 y r s)$ found that children who had partial information about parental multiple sclerosis (e.g. they were aware of a parental health problem but had limited, unspecific or 'developmentally inadequate' information) had more social and emotional difficulties compared to children who had been given either no information, or total disclosure about their parent's condition. In a cross-sectional study in South Africa of HIV-positive mothers ( $n=395)$ with children aged 6-10 years, only 29 had been informed of their mother's HIV status and 18 had received partial disclosure (told that their mother was sick). This latter group had fewer internalising and externalising behaviours and improved skills of daily living, compared to those who had been told nothing. ${ }^{36}$ However there was no such association for those explicitly told about HIV compared to the non-disclosure group. The differences between these two studies may reflect the specific complexity of HIV disclosure, although the small sample sizes limit the interpretation.

\section{Evidence drawn from intervention studies}

Intervention programmes for families experiencing parental LTCS have sought to facilitate communication between parents and children (Table 2 appendix). Evaluation of these programmes provides some evidence of their benefit, although identifying the specific elements responsible for positive outcomes remains difficult.

The Enhancing Connections programme in the USA for mothers with cancer $(n=176)$ included sessions to develop the mother's listening skills, understanding the child's experience as distinct from her own, and strategies to encourage the child's emotional expression. ${ }^{37}$ Significant reductions were seen in both child (8-12yrs) behavioural and emotional problems post intervention. Improvements in parentchild communication were found in a pilot RCT (TRACK) in the USA which aimed to help with communication skills for HIV-positive mothers $(n=80)$ and provide practical advice on disclosure. ${ }^{38}$ Children (6-12yrs) showed improvements in anxiety, depression and happiness scores, although only $33 \%$ of mothers actually disclosed during the study. Evaluation of an uncontrolled five/six session intervention in Denmark aiming to facilitate open communication about illness for parents with cancer ( $n=41$ adults, $n=34$ children) indicated a significant decrease in depression scores for children (8-15yrs) post intervention. ${ }^{39}$ An intervention, beginning prior to parental death, in the USA which included work on family communication ( $n=184$ children and parents) found no significant differences in children's emotional symptoms between intervention and control groups. ${ }^{40}$ However, from pre- 
bereavement to 6 months after death, greater decreases in child (7-17yrs) anxiety and depression scores were reported for the intervention arm.

An RCT in the USA with parents diagnosed with HIV/AIDS $(n=307)$ and their adolescents $(n=412 ; 11-$ 18yrs) compared an intervention to improve behavioural and mental health outcomes of adolescents and their parents relative to standard care. ${ }^{41}$ The initial eight parent-only sessions focussed on coping with illness and disclosure. The sixteen subsequent parent and adolescent sessions included: parental awareness of children's needs, making custody arrangements and resolving conflicts. Adolescent topics included disclosure of a parent with HIV/AIDS, dealing with stigma and encouraging safer sex. The intervention group had significantly better adolescent outcomes (adolescent-report): lower levels of emotional distress and family-related stressors, fewer behavioural problems and higher levels of self-esteem than the control group at 24-months follow-up. Parents in the intervention group had lower levels of emotional distress and fewer problem behaviours relative to the control group. ${ }^{41}$ For both groups, levels of disclosure were high; at study entry $71 \%$ had disclosed to at least one adolescent within the family, and at the 2 year follow-up disclosure had increased to over $85 \%$ of all adolescents in the family.

Interventions to facilitate communication about parental LTC (specifically HIV) have been evaluated in LMICs. In a rural South African population with high levels of HIV, a RCT ( $n=464 ; 6-10 y r s$ ) was conducted to test whether an intervention ('Amagugu'), consisting of six home-based counselling sessions delivered by lay counsellors increased HIV disclosure by HIV-positive mothers to their HIVnegative children. ${ }^{42}$ The intervention included a session for the mother to help her emotionally process the impact of the diagnosis on herself and anticipate children's common reactions and questions following disclosure.. During the sessions the mother and counsellor identified other people with whom the child could discuss HIV. Materials provided to the mother included a 'Body Map' to explain HIV in an age appropriate, non-stigmatising manner. The control group received an enhanced standard of care which included one clinic-based counselling session to promote disclosure. The intervention group was found to have higher rates of maternal HIV disclosure, and improvements in healthcare engagement, care planning for the child and the mother-child relationship. There were no differences between the groups for maternal and child mental health outcomes. However, subsequent analysis showed that where disclosure was undertaken, irrespective of group, it was associated with improvements in maternal and child mental health. ${ }^{42}$

A pilot RCT in Rwanda ( $\mathrm{n}=82$ families; 170 children; 7-17yrs) compared a family strengthening intervention (FSI) to treatment-as-usual (TAU). ${ }^{43}$ The FSI aimed to improve family communication and child mental health, and promote disclosure of parental HIV to children. The intervention consisted of an introductory session and six home-based modules addressing psychoeducation about HIV, communication skills, problem solving and developing a social support network. Parents and children had separate meetings involving psychoeducation and role plays to prepare for a family session to develop a narrative of the family's strengths. At follow-up there were reductions in children's depression scores compared to TAU, but there were no differences in conduct problems or parenting scores. ${ }^{43}$ Parenting and family unity initially decreased but "resolved" over time. The authors suggested this may reflect an initial loss of trust and associated challenges in the family relationship, which is then mitigated by the family-based intervention. ${ }^{44}$ 


\section{2b) What is the impact of communication on parents and the wider family system?}

Studies have found that sharing information can encourage trust between children and parents. A UK qualitative study of mothers with breast cancer $(n=32)$ found that some decided to share the diagnosis with their children ( $n=56 ; 5-18 y r s$ ) in order to maintain trust and facilitate discussion within the family. ${ }^{45} \mathrm{~A}$ qualitative study in Zimbabwe ( $\mathrm{n}=41$ adults; $n=56$ orphans; $7-22 y r s$ ) found that secrecy can leave adolescents with feelings of resentment, broken trust and anger. ${ }^{11}$ Bereaved adolescents felt that telling the truth "is the best thing" and that they had experienced "hatred" towards the surviving members of the family who had withheld information about their parent's illness. ${ }^{11}$

Some studies indicate potential psychological and physical health benefits for parents following interventions to enhance communication with their children around illness. Evaluation of the uncontrolled Danish study (described above) found an increase in family functioning and a significant decrease in depression for mothers post intervention. ${ }^{39}$ An uncontrolled intervention study in South Africa $(n=281)$ designed to facilitate maternal disclosure to HIV-negative children (6-10yrs), found significant improvements in maternal mental health and emotional functioning, although these benefits occurred irrespective of whether the mothers disclosed to their children during the course of the study. ${ }^{46}$

There may also be physical health benefits of communication; mothers with HIV ( $n=135$ ) in the USA who had not disclosed their status reported sometimes skipping medications because they were afraid their children (6-11yrs) would observe them and then suspect something was wrong. ${ }^{26}$ These mothers were also more likely to miss medical appointments than those who had disclosed their status.

\section{3a) What factors influence the process of communication?}

Studies have explored factors that might influence communication with children about their parent's condition, including child's age and gender, family sociodemographic factors, parental health and illness beliefs (figure 1). 


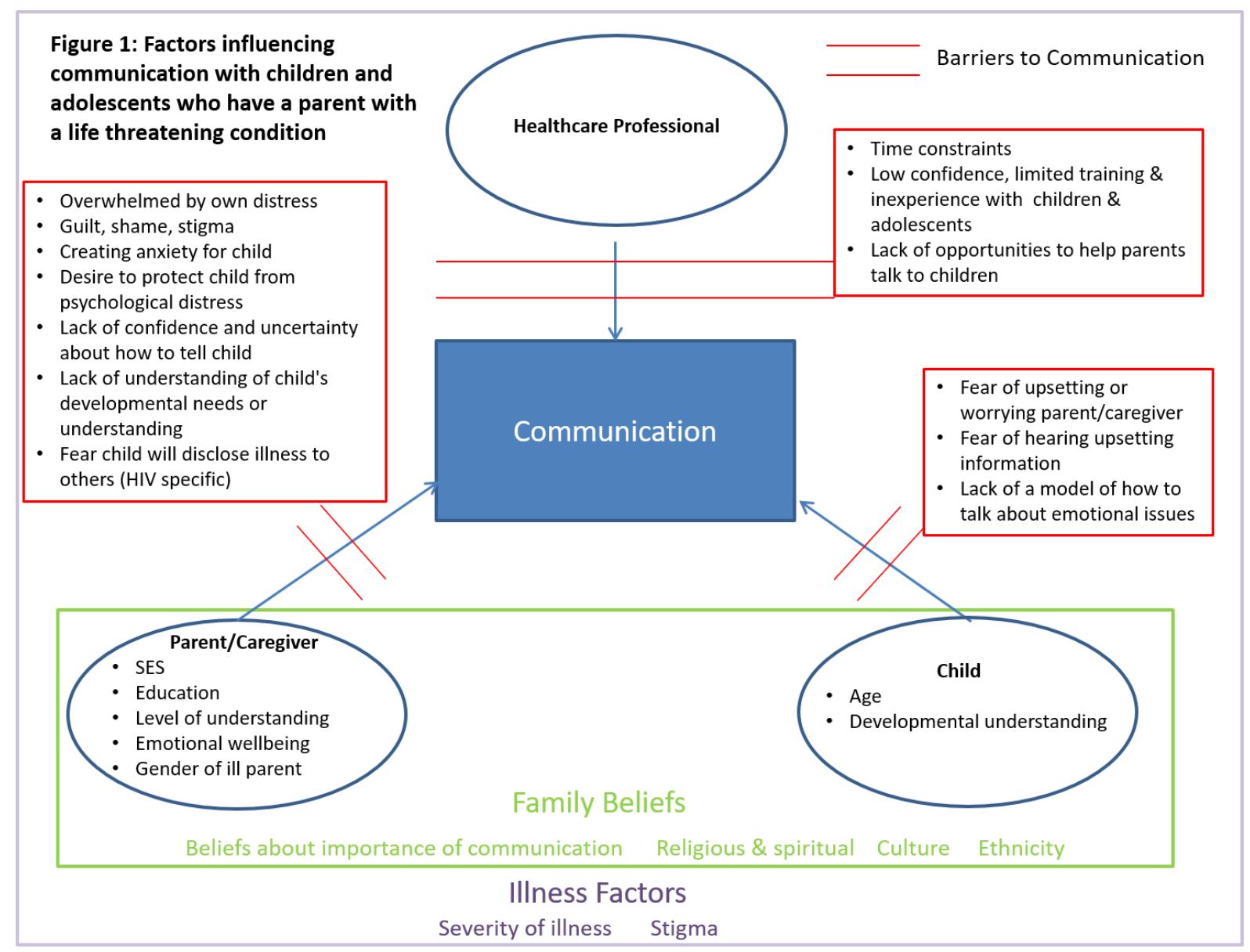

\section{Age of child}

Evidence from studies examining HIV disclosure found that parents are more likely to disclose their status to older children. ${ }^{10,35,47}$ Focus groups with HIV-positive mothers $(n=60)$ in India reported that $38 \%$ of women suggested it was best to wait until their children (0-10yrs) were older (some reporting this to be at least 15 years old) and able to understand the impact of HIV on the family. ${ }^{48} \mathrm{~A}$ UK study found that child's age predicted when communication about breast cancer occurred between mothers $(n=32)$ and their children ( $n=56 ; 5-18 y r s)$, with older children (12 years and over) more likely to be told earlier and given information. ${ }^{49}$ These studies also suggest parents may underestimate younger children's awareness of parental illness ${ }^{13,14}$ and understanding of illness and death (see child LTC paper). Parental LTCs may pose specific challenges for adolescents; their more advanced cognitive skills may lead them to understand more, and appreciate the potential gravity of their parent's situation..$^{50}$ Illness may also complicate the attainment of adolescent developmental tasks of separation and individuation (see child LTC paper).

\section{Sociodemographic characteristics}

Some studies have found no relationship between rates of HIV disclosure and ethnicity, marital status, religion, employment status, socioeconomic status, race, mother's age and educational level. ${ }^{35,47,51}$ However, disclosure was related to income in a group of African American mothers ( $n=87$; children 611yrs) where disclosure was more likely in families with lower incomes. ${ }^{47}$ In addition, a South African study found mothers ( $n=281$; children 6-10yrs) with a current partner were more likely to fully disclose their HIV status than those not in a partnership, ${ }^{52}$ but this was not replicated in a US study $(n=88$; 
children 5-18yrs). ${ }^{51}$ Mothers were also more likely to disclose their HIV status to their daughters rather than their sons, ${ }^{35,47}$ and mothers were more likely to disclose their status earlier than fathers. ${ }^{35}$

\section{Severity of parental illness}

The decision to communicate parental LTC appeared to be influenced by the severity of the illness, with disclosure more common among parents who were in poorer health. ${ }^{35,53}$ A quantitative study of HIV-positive mothers ( $n=281$; children 6-10yrs) in South Africa, found those who considered their health diagnosis as "excellent" were less likely to disclose their diagnosis. ${ }^{52}$ Disclosure of HIV can also be related to the severity of physical symptoms, with a higher percentage of disclosure in families where mothers ( $n=87 ; 6-11 y r s$ ) reported being more "bothered" by physical symptoms. ${ }^{47} \mathrm{~A}$ parent $(n=21)$ becoming very sick was reported as a compelling reason for disclosure to their children $(n=24$; 5 -18yrs) in a qualitative study in Botswana. ${ }^{10}$

In contrast, a Dutch quantitative study ( $n=212 ; 11-18 y r s$ ) found communication was more open (for daughters) and less problematic (for sons) when parents were undergoing non-intensive (surgical only) treatment for cancer, compared to those on intensive treatment regimens. ${ }^{31}$ Daughters also rated communication with the ill parent as significantly more open than that with the unaffected parent, although this could relate to the gender of the ill parent (predominantly mothers in this study). ${ }^{31}$

\section{Parental beliefs around disclosure}

Parents expressed varied motivations for disclosing their HIV status including avoiding unexpected shock if the parent dies; making sure the family knew the real cause of their illness (and death); and protecting children from stigma and feelings of hurt if their child learnt the cause from someone else. ${ }^{54}$ Some parents hoped disclosing their HIV status to their children would alert them to the risks of becoming infected with HIV through unprotected sex or drug use. ${ }^{54,55}$

Studies have noted the consequences and difficulties parents have experienced by not disclosing their HIV status; parents were concerned they would accidentally disclose their status in a moment of stress or high emotion. ${ }^{53,56}$ These situations deny the parent time to prepare and/or make the communication process as supportive as possible. In addition, by keeping their HIV status secret the implicit message communicated is that HIV is stigmatising and must be hidden. ${ }^{35}$

\section{3b) What are the barriers and challenges to communication (figure 1)?}

\section{Barriers experienced by children}

Children's difficulties in communicating about LTCs mirror themes expressed by parents, with children reporting that communication is often impeded by fears of upsetting their parents and a desire to protect their parents by avoiding talking about illness. ${ }^{17,24}$ Children ( $\left.n=7 ; 11-15 y r s\right)$ reported finding it difficult to initiate conversations with parents. ${ }^{57}$ Difficulties may be related to a sense of guilt and selfishness about burdening parents with their own feelings. ${ }^{58}$ Children's avoidance of talking with their parents can in part be due to not wanting to hear upsetting information. ${ }^{57}$ Similarly the fear of losing a parent can lead to barriers; in one study sons reported more problems in communicating with parents who had a recurrence of their illness. ${ }^{31}$ Children may be aware something is wrong, but feel that they do not actually want to know what it is. A qualitative study in the USA ( $n=87 ; 7-11 \mathrm{yrs}$ ) found 
some children experienced a "frightening anticipation" and simultaneous need for denial of their parent's possible death and thus would not communicate with their family. ${ }^{18}$ Interestingly, teacher's ratings of child behavioural difficulties were higher than by parental-report, suggesting children $(n=80$; 8-16yrs) are more likely to manifest their emotional distress at school rather than home. ${ }^{32}$

\section{Barriers experienced by parents}

Parents often do not know how to tell their children about their illness ${ }^{10,24}$ and want support, ideally from a HCP. ${ }^{59}$ Studies indicate that parents do not talk to their child about their illness as they believe their child is too young or unable to understand. ${ }^{45,54}$ Parents report feeling unsure about how much information is appropriate, ${ }^{60}$ at what age they should talk to their child, ${ }^{54}$ or how information should be tailored to their child's age and developmental ability. ${ }^{24,45}$ Parents ( $n=18$; children under 18yrs) can lack confidence in how to respond to children's reactions or questions, ${ }^{59}$ particularly about death ${ }^{45}$ and find it difficult to be honest when the illness has an uncertain course or prognosis. ${ }^{61}$

Parents often fear being overwhelmed by their own distress; ${ }^{60}$ guilt about not being able to fulfil their role as parents and grief about missing their child growing up into adulthood. ${ }^{24}$ Parents worry about how to manage the reactions of their children in response to the information given and as a result may rely on technical or factual language in an attempt to minimise emotional reactions. ${ }^{60}$ Studies both in HICS and LMICs highlight parents' fear of causing their child distress ${ }^{10,15,34,54,62}$ creating anxiety, ${ }^{10,45}$ or an unnecessary psychological burden. ${ }^{55,63}$ Two studies from LMICs also highlighted parental concerns that disclosure of their HIV status would have a negative impact on their child's academic performance at school. . 8,63

Parents with HIV reported specific challenges linked to the sense of shame and stigma sometimes associated with HIV. ${ }^{10,62}$ Parents worried that their child would experience discrimination and stigmatisation from others. They feared that children would not keep information about their diagnosis confidential ${ }^{10,12,48,54}$ and that disclosure would increase the vulnerability of the family. ${ }^{26}$ Parents expressed concern about the potential response of their children to the news of their HIV status, fearing rejection, ${ }^{55}$ a loss of respect from their child, ${ }^{54}$ discrimination ${ }^{48}$ or a refusal to care for them. ${ }^{63}$ Potential embarrassment at coping with questions about how the disease was contracted and fear that this might raise broader questions about sexual relationships (which is taboo in some cultures) also contributed to parents' reluctance to talk to their children. ${ }^{54,55}$ The relationship between stigma and parental disclosure is inconsistent; parents who perceived their children to be experiencing higher HIV-related stigma were more likely to disclose ${ }^{35}$ while another study found no such association. ${ }^{64}$

A German study using cancer-registries found that while $66 \%$ of cancer survivors ( $n=1809$ ) with children (under 22yrs) wanted support about how to tell children about cancer, only $9 \%$ accessed such provision. ${ }^{6565} \mathrm{~A}$ systematic review of interventions for families with parental cancer identified 'barriers and facilitators' for engagement with psychosocial support services. ${ }^{66}$ This highlighted the perceived importance for parents of interventions that were appropriately structured and targeted, in addition to consideration of practicalities such as childcare that would enable access. Evaluation of a support group for parents $(n=21)$ with recurrent cancer noted that parents had not anticipated positive gains for themselves from attendance, but overcame their reservations if they felt it might benefit their 
children ( $n=30 ; 4-8 y r s) .{ }^{67}$ Despite these hesitations, parents reported finding the group a valuable experience, underlining the importance of engaging parents when planning interventions.

\section{Barriers within parent-child relationship}

Parent-reported communication may differ from child-reported experiences. ${ }^{21}$ Parents may try to conceal and control their own distress in order to protect their children, but in a study of fathers $(n=26)$ and children ( $n=31 ; 6-18 y r s)$ who had a mother with breast cancer, children were often acutely aware of their father's emotional state and in turn concealed their own distress to protect their father. ${ }^{21}$ Fathers reported that they had "fully reassured" their children about their mother's health, yet children still described remaining worried.

The extent to which parents are able to accurately assess their child's understanding, and consequently tailor communication, has been questioned. ${ }^{17}$ When a parent is unwell they are usually the main source of their child's information about the illness and thus the information children receive is filtered by their parents' beliefs, health status, ability to regulate their own emotional state and communication skills. ${ }^{17}$ Parents often take on a teacher/educator role, with a focus on sharing factual information. ${ }^{17}$ The success of this communication style may be limited if parents do not first check their child's understanding (which may be greater than suspected by parents) or elicit their child's

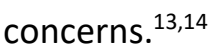

Although parents often adopted a model of communicating facts rather than emotions, parents wanted their children to share more of their feelings. ${ }^{17}$ Interestingly, children reported that their parents were similarly uncommunicative about their own emotions. Parental focus on practical aspects of illness may reflect parental fear about how to manage powerful and upsetting emotional conversations, and how to adequately contain and manage their child's reaction. ${ }^{17}$ Parents' concern about revealing the extent of their own distress can create difficulties in communication about emotional issues between parents and children. Children are often aware of how their parents are feeling, but strive to protect them by concealing their own distress. ${ }^{21,60}$ Parents may also interpret their child's response in the context of their own preferred coping style; parents who preferred not to talk about their illness perceived their child was coping well when they did not ask questions. ${ }^{60}$ Conversely, parents with an open communication style viewed children's questions as a sign of successful coping.

\section{Contextual barriers}

HCPs working in adult-focused services may feel inexperienced about talking to children and adolescents about parental illness. They may feel unprepared to facilitate the care patients want and expect in supporting their family throughout the illness and in bereavement. ${ }^{60}$ In some LMICs clinics may be a long distance from the family home, providing few opportunities for the HCP to help the parent talk to their children. ${ }^{68}$ Often the HCP responsible will have received no, or limited training in helping with communicating about illness $(n=35) .{ }^{69}$ There are also cultural differences in preparing for death; in some communities around the world talking about death or dying is considered taboo. ${ }^{70}$ 
4) What are the reported preferences of children, adolescents and parents about the way the diagnosis and information is conveyed?

The research literature identifies themes that are important to children, adolescents and their parents in the content and delivery of communication (Box 1). It is important to acknowledge that the majority of child participants were adolescents with cancer from HICs, but their views offer invaluable and practical guidance for HCPs applicable across multiple healthcare settings. The preferences should be viewed in the context of children's developmental understanding of illness and death (see review of child LTC).

BOX 1: The preferences of children, adolescents and parents/caregivers about the way diagnosis and information is conveyed

\section{Children's preferences about how information is communicated}

1. Information: children consistently report wanting prompt, clear, simple information about their parent's diagnosis, planned treatment and prognosis. ${ }^{22,71,72}$

a. Risk of creating anxiety is outweighed by children's desire for information. ${ }^{17,73}$

b. Want more information when their parent becomes sicker. ${ }^{22}$

c. Some children want parents to filter, or "soften", the information according to what they feel able to deal with. This can create tension between conflicting desire for complete honesty and reassurance that everything will be alright. ${ }^{24}$

d. Paced information so there is time to process content and avoid feeling bombarded or overwhelmed. 22,58

e. Specific information about parent's care needs so they can help and be useful. ${ }^{17,24}$

f. Information about side effects and changes associated with the illness or treatment (such as "grumpiness", appearance post-operatively or hair loss following chemotherapy). Enables children to prepare themselves and reduces feelings of anxiety. ${ }^{21,22}$ Ensures that children do not misinterpret normal treatment side effects as deterioration in their parents' health. ${ }^{58}$

g. Information about range and intensity of emotions experienced by other adolescents in same situation. ${ }^{22}$

\section{Sources of information}

a. Direct and honest information from parents as early as possible. ${ }^{73}$

b. Information from parent's clinician

i. Information from a knowledgeable source. . $^{21,22}$

ii. Ability to obtain information without fear of upsetting parent. ${ }^{60}$

iii. Visit to clinic can dispel scary fantasies about treatment and "humanise" the doctor. ${ }^{58}$ Phone number is helpful even if never used. ${ }^{22}$

iv. Need HCPs to be proactive as hard to approach them directly. ${ }^{24}$

v. Children want their own relationship with HCP to be maintained. ${ }^{74}$

3. Language: avoid jargon to reduce confusion. Self-referential language should also be used with caution; "they will cut me open" may be more distressing to hear than an objective description using language that disconnects it from the parent-patient ${ }^{58}$ (e.g. the doctor is going to do an operation to remove the tumour).

4. Opportunities for emotion focused communication: children want opportunities to talk and express their feelings.

a. Peer support; children often feel isolated from their peer group who have little understanding or knowledge of the challenges facing their family $14,73,75$ and want to meet others living through similar experiences in person or online. ${ }^{75}$ 


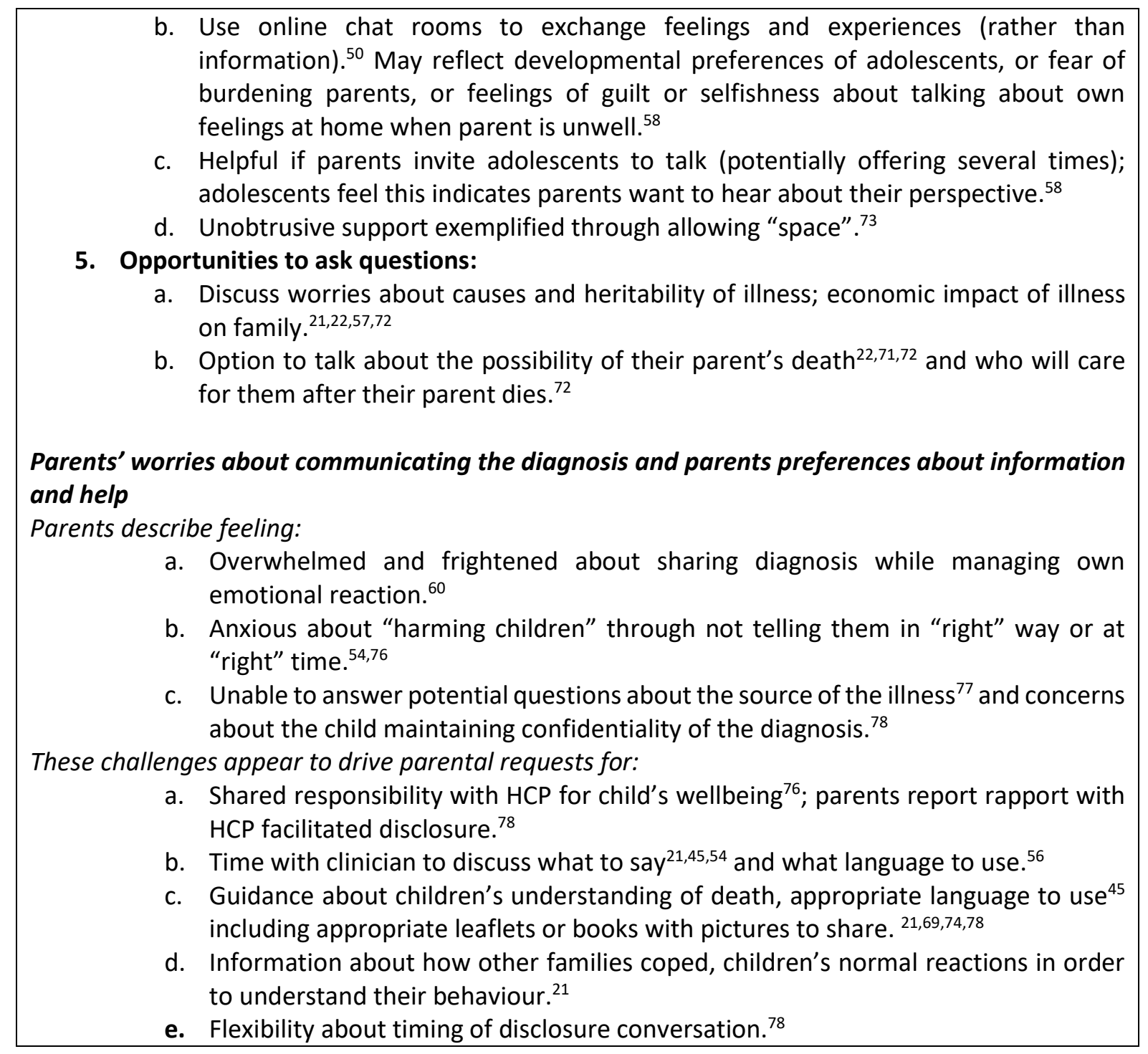

\section{Expert Group Workshop and Development of Framework}

The expert group of clinicians and researchers with extensive experience of working with families affected by LTC in HICs and LMICs met for a two day workshop in Oxford, UK in 2017 (see review of child LTC).

In developing these guidelines (box 2), we appreciate that a range of HCPs will be involved in these discussions; in HICs these will more likely be oncologists, family practitioners or infectious disease specialists, while in LMICs, these will be medical officers, nurses or community healthcare workers. Different cultures must be considered, and what is appropriate to discuss with children must be considered, whilst upholding the principles of the UN Convention on the Rights of the Child. ${ }^{79}$

\section{Limitations and Future Directions for Research}

The literature is complicated by methodological difficulties; participants have been recruited from a range of sources, most frequently through the parent's hospital oncology or HIV services, but also from charities and voluntary organisations, community adverts ${ }^{16}$ or population-based surveys. ${ }^{15}$ Most research has also focussed on mothers rather than fathers. Comparison of studies can be 
compromised by differences in the stage of parental illness at the time of data collection ranging from newly diagnosed ${ }^{21}$ to 10 years since bereavement. ${ }^{15}$ Some studies restricted participants to a relatively discrete time frame e.g. 2-5 months since diagnosis ${ }^{14}$, whereas others were much more wideranging. ${ }^{31,33}$ These factors may contribute to a loss of detail and specific needs at particular stages of the disease, or conversely the value of reflection on the whole illness journey, and how communication needs may change over time.

The influence of the socioeconomic and geographical context on treatment availability and prognosis also affects generalisability. Work in LMICs is almost exclusively limited to parents with HIV (rather than other conditions) and the specific stigma associated with HIV may affect the relevance of findings from this group for other LTCs. Only three studies conducted in LMICs (all qualitative) directly involved children as research participants (in contrast to HICs); future research must strive to sensitively include children as active participants. Most studies recruited children over the age of 11 which may limit the applicability of research in younger children, although children as young as 6 have been interviewed. ${ }^{14}$ The relatively wide spread of ages within individual studies ${ }^{14}$ risks overlooking the specific needs of different age groups and developmental transition points.

The fear of the emotional impact of diagnostic conversations on HCPs, parents and children is the predominant, underlying reason for these not occurring. Similar concerns may also extend to and inhibit the research agenda. Identifying what support is required to overcome these emotional barriers and how this could be sustainably delivered, particularly in contexts where the disease burden is high and resources are limited, is needed. A programme of formal communication skills training is critical, both in medical schools and other healthcare curricula, as well as part of continuing professional development for frontline HCPs. Evaluation of training and how this translates into enhanced clinical practice is essential. ${ }^{7}$

Models of family-centred care (in paediatrics) which acknowledge the impact of a child's illness on all members of the family, have been adopted in many HICs. ${ }^{80}$ Given the impact of parental illness on child outcomes, it is timely to consider how a similar model could be of benefit in the management of adult patients and their families. As a minimum, services should provide proactive support and guidance for parents about communicating diagnoses to children. Adult clinicians should take overall responsibility for ensuring parents have support and should discuss with parents whether they would like an appropriately trained HCP to facilitate this directly through a family consultation.

Communication is not a single event, and following diagnostic conversations there remains a need for ongoing communication. Families may be supported by other services or the wider community including charitable and voluntary organisations, although availability varies widely across LMICs and HICs. Building an infrastructure to provide support around family communication requires recognition of the training, time and financial commitment involved. Research generally focuses on communication and the relationship between family members and hospital-based HCPs, at the expense of considering the roles and responsibilities of professionals in the wider healthcare and community system e.g. family/general practitioners, spiritual leaders and school staff. It is essential there is discussion amongst all HCPs involved to decide who will take lead responsibility for addressing the children's communication needs. 
Principles to assist health-care professionals communicating with parents and children about parental life-threatening conditions

\begin{tabular}{|c|c|c|c|c|}
\hline Principle & Detail & Challenges & $\begin{array}{l}\text { Suggested Phrases for } \\
\text { Parent }\end{array}$ & $\begin{array}{l}\text { Suggested Phrases for } \\
\text { Children }\end{array}$ \\
\hline Prepare information & $\begin{array}{l}\text { Try and establish if patient has children. } \\
\text { Consider what ongoing input you are able to offer } \\
\text { parents and children (e.g. availability for direct } \\
\text { contact with children). } \\
\text { Check you know the names of the parents and } \\
\text { names and ages of children. This is important to } \\
\text { ensure language and content is developmentally } \\
\text { appropriate. Addressing family members by name } \\
\text { will make the consultation more personal. } \\
\text { Consider how to initiate the conversation about } \\
\text { patient's children. }\end{array}$ & $\begin{array}{l}\text { May be difficult to } \\
\text { establish if adult patient } \\
\text { has children (e.g. in the } \\
\text { Accident and } \\
\text { Emergency } \\
\text { Department). } \\
\text { Adult clinicians may feel } \\
\text { unskilled or } \\
\text { inexperienced talking } \\
\text { about children. }\end{array}$ & $\begin{array}{l}\text { "Can you tell me about } \\
\text { your family?" } \\
\text { "Who lives at home } \\
\text { with you?" }\end{array}$ & \\
\hline $\begin{array}{l}\text { Prepare } \\
\text { environment }\end{array}$ & $\begin{array}{l}\text { Consider suitable location (quiet or private) and } \\
\text { timing of conversation with parents (both if possible) } \\
\text { and children. }\end{array}$ & $\begin{array}{l}\text { Private or quiet space } \\
\text { may not be available. }\end{array}$ & $\begin{array}{l}\text { "Let's move to this } \\
\text { quieter space so that } \\
\text { we can spend some } \\
\text { time talking together." }\end{array}$ & \\
\hline
\end{tabular}




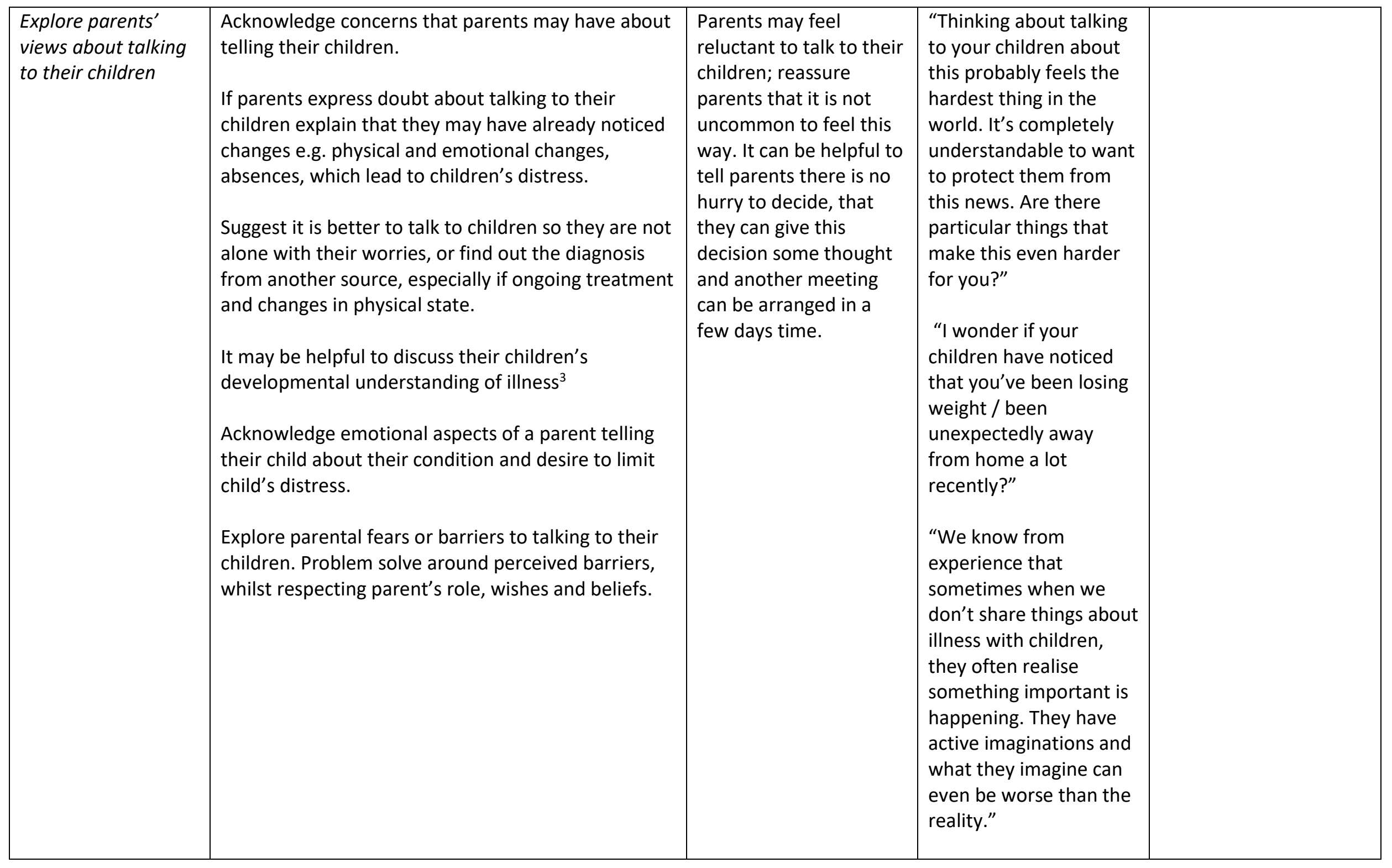




\begin{tabular}{|c|c|c|c|c|}
\hline & & & $\begin{array}{l}\text { "We know that you } \\
\text { know your child inside } \\
\text { and out. We appreciate } \\
\text { you are the expert in } \\
\text { your child and we will } \\
\text { always work with you." }\end{array}$ & \\
\hline Prepare the parents & $\begin{array}{l}\text { Acknowledge and support parent with their own } \\
\text { feelings/distress about their diagnosis. } \\
\text { Prioritise key information for parents. They may } \\
\text { struggle to assimilate information due to fatigue, } \\
\text { pain or emotional distress. } \\
\text { Encourage parent to ask the child how much they } \\
\text { know about the life-threatening condition and pace } \\
\text { subsequent information in response to children's } \\
\text { emotional reactions and wishes. The conversation } \\
\text { may need to take place on several different } \\
\text { occasions. } \\
\text { Discuss with parent how best to describe the life- } \\
\text { threatening condition; suggest simple phrases or } \\
\text { narratives the parent could use to explain the life- } \\
\text { threatening condition to their children, including the } \\
\text { name of their life-threatening condition, what they } \\
\text { may observe, and what they should expect. } \\
\text { Encourage parent to only convey information that is } \\
\text { true and can be elaborated in due course. This is } \\
\text { important to maintain the children's trust in their } \\
\text { parent/caregiver. }\end{array}$ & $\begin{array}{l}\text { If parents are } \\
\text { separated, discuss with } \\
\text { parents who will tell the } \\
\text { children and the } \\
\text { involvement of other } \\
\text { biological parent. }\end{array}$ & $\begin{array}{l}\text { "Would you like to sit } \\
\text { and talk with me now } \\
\text { about how you will tell } \\
\text { your children and what } \\
\text { words you could use? If } \\
\text { you like, we can then } \\
\text { practice this together." } \\
\text { "I know you are } \\
\text { worried that telling your } \\
\text { children will be } \\
\text { upsetting for them. Yes, } \\
\text { it is likely they will be } \\
\text { upset or even angry. } \\
\text { These are natural } \\
\text { emotions and responses } \\
\text { to have. Be assured } \\
\text { that talking to children } \\
\text { is important in helping } \\
\text { them through this } \\
\text { difficult time." } \\
\text { "Younger children may } \\
\text { focus much more on the } \\
\text { practical aspects of how } \\
\text { the life-threatening } \\
\text { condition will change }\end{array}$ & $\begin{array}{l}\text { "Today we went to the } \\
\text { clinic because Dad } \\
\text { hasn't been feeling well. } \\
\text { Shall I tell you a bit } \\
\text { more about what the } \\
\text { doctors told us?" } \\
\text { "You know that Mummy } \\
\text { hasn't been feeling well } \\
\text { and we needed to find } \\
\text { out what was wrong. } \\
\text { We went to the hospital } \\
\text { where the doctors did } \\
\text { some special tests to try } \\
\text { and find the problem. } \\
\text { Today the doctors told } \\
\text { us Mummy is ill because } \\
\text { she has an illness in her } \\
\text { blood called cancer." } \\
\\
\text { "The doctors are giving } \\
\text { Dad some strong } \\
\text { medicine called } \\
\text { chemotherapy to try } \\
\text { and treat the cancer. } \\
\text { We hope this will help }\end{array}$ \\
\hline
\end{tabular}




\begin{tabular}{|c|c|c|c|c|}
\hline & $\begin{array}{l}\text { Suggest to parents they may find it helpful to } \\
\text { prepare a script and practice this before talking to } \\
\text { their children. } \\
\text { Suggest parent may find it helpful to include their } \\
\text { partner, a family member or friend in their } \\
\text { conversation with the children. } \\
\text { Highlight to parent themes from literature about } \\
\text { what children report is important in communication } \\
\text { about life-threatening conditions. } \\
\text { Offer parent resources (e.g. leaflets, story books, } \\
\text { web resources) to share with their children. } \\
\text { Encourage parent to check children's understanding } \\
\text { of what has been communicated and importance of } \\
\text { repeating key messages. }\end{array}$ & & $\begin{array}{l}\text { their day to day life; } \\
\text { who will take me to } \\
\text { school? They might not } \\
\text { show an immediate } \\
\text { reaction to the news } \\
\text { (for example wanting to } \\
\text { go and play) but this } \\
\text { doesn't necessarily } \\
\text { mean they didn't hear } \\
\text { the news and distress } \\
\text { can be shown in other } \\
\text { ways." }\end{array}$ & $\begin{array}{l}\text { him get better, but it } \\
\text { will also make him feel } \\
\text { very tired." } \\
\text { "The doctors and nurses } \\
\text { are trying very hard to } \\
\text { make Mummy better } \\
\text { and I really want } \\
\text { Mummy's medicines to } \\
\text { work but sometimes } \\
\text { medicines do not work." }\end{array}$ \\
\hline
\end{tabular}




\begin{tabular}{|c|c|c|c|c|}
\hline & $\begin{array}{l}\text { Help parent feel confident to reassure their child } \\
\text { that they will be loved and looked after no matter } \\
\text { what the future holds. }\end{array}$ & & $\begin{array}{l}\text { example explain that } \\
\text { you are feeling sad and } \\
\text { that you are crying } \\
\text { because sometimes you } \\
\text { feel a bit sad and you } \\
\text { feel better after a good } \\
\text { cry." }\end{array}$ & \\
\hline Common questions & $\begin{array}{l}\text { Support parent to nurture children's confidence to } \\
\text { initiate conversation and ask question. } \\
\text { Anticipate common questions that children may ask. } \\
\text { Parents may benefit from rehearsing with you how } \\
\text { to answer these questions at a developmentally } \\
\text { appropriate level. This also provides an opportunity } \\
\text { for you to check parents' own understanding of their } \\
\text { condition. } \\
\text { Encourage parent to reassure their children that } \\
\text { their distress is normal and acceptable. } \\
\text { Discuss ways parent can encourage children to ask } \\
\text { questions as they arise and review their children's } \\
\text { feelings regularly. } \\
\text { Discuss with parent the possibility older children } \\
\text { may independently seek further information online, } \\
\text { which may be of varying factual quality. Encourage } \\
\text { parental dialogue with their children about online } \\
\text { information. }\end{array}$ & $\begin{array}{l}\text { Questions about the } \\
\text { possibility of parental } \\
\text { death are disease and } \\
\text { stage specific. } \\
\text { Answers need to } \\
\text { consider child's age and } \\
\text { level of understanding. }\end{array}$ & $\begin{array}{l}\text { "Children often want to } \\
\text { know what caused the } \\
\text { illness and are worried } \\
\text { that it might have been } \\
\text { their fault." } \\
\text { "Children may ask you if } \\
\text { you going to die, who } \\
\text { will look after them and } \\
\text { whether they can catch } \\
\text { it. Shall we plan how } \\
\text { you might deal with } \\
\text { these questions at } \\
\text { home?" } \\
\text { "Would it be helpful to } \\
\text { have a session with you } \\
\text { and your children } \\
\text { together?" } \\
\text { If child asks "Are you } \\
\text { going to die?" } \\
\text { depending on prognosis } \\
\text { one can say "That's a } \\
\text { difficult question to }\end{array}$ & $\begin{array}{l}\text { "Would you like to talk } \\
\text { to the doctors; you can } \\
\text { come with me one of } \\
\text { my clinic visits?" }\end{array}$ \\
\hline
\end{tabular}




\begin{tabular}{|c|c|c|c|}
\hline & & $\begin{array}{l}\text { answer but we do } \\
\text { know, from talking to } \\
\text { the doctors, that they } \\
\text { are going to do } \\
\text { everything they can to } \\
\text { help me" }\end{array}$ & \\
\hline Future thinking & $\begin{array}{l}\text { Discuss with parent how they can involve children in } \\
\text { day-to-day aspects of the life-threatening condition. } \\
\text { Encourage parent to establish a 'new normal' while } \\
\text { maintaining boundaries and hobbies where feasible. } \\
\text { Encourage the parent to share the practical and } \\
\text { emotional burden with the well parent, family and } \\
\text { friends. If parents are separated, discuss the benefits } \\
\text { of maintaining a consistent message for their } \\
\text { children. } \\
\text { Identify who else knows about the life-threatening } \\
\text { condition and who the child can talk to. } \\
\text { Explore the importance of children's teachers and } \\
\text { school. } \\
\text { Identify ongoing sources of support and community } \\
\text { resources (e.g. parent groups, voluntary sector, } \\
\text { online forums or websites, written story books and } \\
\text { other resources such as } \\
\text { http://www.compassionbooks.com/categories/Serio } \\
\text { us-and-Life\%252dThreatening- } \\
\text { Illness/?sort=featured\&page=2). } \\
\text { Discussion may need to include consideration of } \\
\text { who will care for the children if the parent is }\end{array}$ & $\begin{array}{l}\text { "If you can, do accept } \\
\text { offers of practical help } \\
\text { or emotional support } \\
\text { from friends and family } \\
\text { with whom your } \\
\text { children feel } \\
\text { comfortable, in order } \\
\text { to keep their day to day } \\
\text { routine." } \\
\text { "Children spend a large } \\
\text { amount of time at } \\
\text { school and so it is } \\
\text { important for the school } \\
\text { to understand what } \\
\text { your child is going } \\
\text { through. School can also } \\
\text { be a really helpful } \\
\text { source of support for } \\
\text { your child. Try to keep } \\
\text { the school up to date." } \\
\text { "It will be really helpful } \\
\text { for your children to } \\
\text { have somebody to talk } \\
\text { to outside of the family. } \\
\text { Being able to share their }\end{array}$ & $\begin{array}{l}\text { "I know it can feel scary } \\
\text { when you don't feel } \\
\text { sure about what's going } \\
\text { to happen. I feel that } \\
\text { way sometimes too. } \\
\text { What I do know for sure } \\
\text { is that I love you very } \\
\text { much. We will work } \\
\text { through this together as } \\
\text { a family, whatever the } \\
\text { future holds." }\end{array}$ \\
\hline
\end{tabular}




\begin{tabular}{|l|l|l|l|}
\hline & $\begin{array}{l}\text { hospitalised, or for single parents, custody } \\
\text { arrangements. }\end{array}$ & $\begin{array}{l}\text { feelings without } \\
\text { worrying about } \\
\text { upsetting you is really } \\
\text { important. }\end{array}$ \\
\hline
\end{tabular}




\section{Acknowledgments}

The study was funded by The John Fell Fund, University of Oxford and The Sheila Kitzinger Programme, Green Templeton College, Oxford supported the workshop.

We are grateful to Duncan West and Melissa de Lusignan for facilitating the expert workshop. We are also grateful to Valerie West, Mike Beckles, Nia Roberts, Hannah DeJong, Elise Sellars and patient and public involvement from a parent with cancer (written permission obtained).

\section{Authors' contributions}

Alan Stein (AS) conceptualized and designed the review. Louise Dalton (LD), Lucy Hanington (LH), and AS undertook the literature searches and selected the studies. AS, LD and Elizabeth Rapa (ER) gathered the information from the studies and drafted the manuscript. Sue Ziebland (SZ), Tamsen Rochat (TR), Aisha Yousafzai (AY), Brenda Kelly (BK) and Ruth Bland (RB) contributed to writing specific sections of the manuscript. Communication Expert Group commented on drafts of the manuscript and contributed to the development of the guidelines. LD and ER compiled the tables. All authors have read and approved the final version of the Review.

\section{Conflict of Interest statements}

EH declares she is deputy chair of the NICE clinical guideline development committee for NG61 (End of Life Care in Infants, Children and Young People').

All of the other authors declare no Conflicts of Interest.

\section{Role of funding source}

The funder of the study had no role in any aspect of the review.

\section{Communication Expert Group:}

Professor Theresa Betancourt SC.D., Boston College, Massachusetts, USA

Professor Myra Bluebond-Langner PhD. UCL Great Ormond Street Institute of Child Health, London, UK

Catherine D'Souza MRCP. South Canterbury District Health Board, New Zealand

Mina Fazel MRCPsych. University of Oxford, Oxford, UK

Kim Fredman Stein MSc. Department of Psychology, University of Bath, Bath

Emily Harrop PhD. Oxford University Hospitals NHS Foundation Trust and Helen \& Douglas House, Oxford, UK 
Professor Daniel Hochhauser DPhil. UCL Cancer Institute, London, UK

Barbara Kolucki MA. Communication and Children in Difficult Circumstances Consultant, UNICEF, New York, USA

Aoife C Lowney MRCP. Oxford University Hospitals NHS Foundation Trust and Sir Michael Sobell House, Oxford, UK

Elena Netsi D.Phil. University of Oxford, Oxford, UK

Professor Linda Richter PhD. University of the Witwatersrand, Johannesburg, South Africa 


\section{Appendix}

\section{Methods}

1. Literature Review

A narrative approach was adopted to provide a comprehensive overview of the available literature and address the wide ranging research questions outlined above. This inclusive methodology was particularly important given the breadth of available literature, ranging from large scale randomised controlled trials (RCTs) to qualitative studies exploring the detail of patient experiences. The search strategy focused on publications since 2000. However, in the context of evolutionary changes in healthcare philosophy around communication, different rates of change across high income countries (HICs) and LMICs, and gaps in the recent literature, we also included consideration of earlier studies (see Box 1 and Box 2 for search strategy and selection criteria).

\section{Expert Group Meeting and Development of Framework}

In the context of the available research evidence and limited child-focused, evidence-based guidelines, an interdisciplinary expert group was convened to synthesise the theoretical, academic and clinical experience of the members to develop a framework for communication. The workshop was attended by 16 professionals and an additional 4 members contributed to subsequent discussions, review and framework development to create an expert group $(n=20)$. The group members had experience of working in HICs (Denmark, Sweden, UK, USA) and LMICs (Cameroon, Laos, Mozambique, Myanmar, Pacific Countries of Vanuatu and Fiji, Pakistan, Rwanda, Sierra Leone, South Africa, Tajikistan, Tanzania, Timor-Leste, Uganda) with backgrounds in psychology, psychiatry, paediatrics, oncology, palliative care, global health, child development, child protection, health and human rights, education, anthropology and sociology. The workshops included presentations on the literature review in HICs and LMICs and the academic and clinical work of the assembled group. Although caregivers and children were not direct participants of this workshop, a series of videos presenting parents' perspectives about talking to children about LTCs were reviewed (these have been published as a clinical and training resource at http://healthtalk.org/content/talking-children-about-parents-lifethreatening-illness). Following extensive discussion, core principles were derived for use in developing a framework. This was then further refined through consensus to create a basic framework. During this iterative process, information gaps were identified and future research directions discussed. The framework was also reviewed by a parent currently undergoing treatment for cancer. We use the term parent throughout, but note that in some circumstances it may be a caregiver rather than a parent. 
Data for this Review were identified using CINHAL (EBSCOHOst)[January 1982- May 2016], Embase (OvidSP)[January $1^{\text {st }}$ 1974- May 11 2016], Medline(OvidSP)[January 1946-May 2016], PsycINFO(OvidSP)[January 1967-April 2016], Science Citation Index \& Social Science Citation Index(Web of Science Core Collection)[January 1945- May 2016]. We used a combination of keywords in title/abstract and subject headings for the following key concepts: children, communication and life-threatening illness and we applied a search filter to identify systematic reviews of qualitative studies. Commentary, letters, conference abstracts, dissertations and case reports were excluded. See appendix for search strategy. 5427 records were identified of which 2132 were duplicates. 2281 potentially relevant articles and reviews were reviewed by LH and LD. Our final sample consisted of 43 articles from the search and an additional 34 articles identified from references of relevant articles.

BOX 2: Search strategy used in Medline (OvidSP)[from 1946]. Other strategies are available on request.

\begin{tabular}{|l|l|l|}
\hline$\#$ & Searches & Results \\
\hline 1 & $\begin{array}{l}\text { (child* or schoolchild* or pediatric* or paediatric* or boys or girls or adolescen* } \\
\text { or teen* or youth? or young people or young person?).ti. }\end{array}$ & 882902 \\
\hline 2 & communication/ or information seeking behavior/ & 69970 \\
\hline 3 & $\begin{array}{l}\text { (nurse-patient relations/ or physician-patient relations/) and (communicat* or } \\
\text { talk* or discuss* or disclose? or disclosure).mp. }\end{array}$ & 29711 \\
\hline 4 & $\begin{array}{l}\text { (parent-child relations/ or father-child relations/ or mother-child relations/) and } \\
\text { (communicat* or talk* or discuss* or disclose? or disclosure).mp. }\end{array}$ & 9697 \\
\hline 5 & Truth Disclosure/ & 12260 \\
\hline 6 & (communicat* or talk* or discuss* or disclose? or disclosure).ti. & 97059 \\
\hline 7 & $\begin{array}{l}\text { ((communicat* or talk* or tell* or told or discuss* or disclose? or disclosure) adj3 } \\
\text { (truth or diagnos* or prognos* or death or dying or terminal*)).ti,ab. }\end{array}$ & 20672 \\
\hline 8 & 2 or 3 or 4 or 5 or 6 or 7 & 191951 \\
\hline 9 & 1 and 8 & 14897 \\
\hline 10 & $\begin{array}{l}\text { ((communicat* or talk* or discuss* or disclose? or disclosure) adj3 (child* or } \\
\text { schoolchild* or pediatric* or paediatric* or boys or girls or adolescen* or teen* } \\
\text { or youth? or young people or young person?)).ti,ab. }\end{array}$ & 12176 \\
\hline 11 & 9 or 10 & 23230 \\
\hline 12 & Attitude to Death/ & 14364 \\
\hline 13 & exp Terminal Care/ or Terminally lll/ & 46221 \\
\hline 14 & Palliative Care/ & 44439 \\
\hline 15 & exp Advance Directives/ & 6332 \\
\hline 16 & ((lifethreaten* or life threaten* or terminal*) adj2 (ill* or condition?)).ti,ab. & 13522 \\
\hline 17 & $\begin{array}{l}\text { (advanced directive? or living will? or "do not resuscitate" or resuscitation order? } \\
\text { or assisted suicide?).ti,ab. }\end{array}$ & 5701 \\
\hline 18 & ((place or home or hospice) adj2 (die or dying or death)).ti,ab. & 2190 \\
\hline 19 & $\begin{array}{l}\text { ((palliative or hospice? or "end of life" or terminal) adj2 (care or therap* or } \\
\text { treat*)).ti,ab. }\end{array}$ & 36763 \\
\hline
\end{tabular}




\begin{tabular}{|c|c|c|}
\hline 20 & $\begin{array}{l}\text { *neoplasms/ or exp *breast neoplasms/ or exp *colorectal neoplasms/ or exp } \\
\text { *testicular neoplasms/ }\end{array}$ & 647765 \\
\hline 21 & exp *leukemia/ or exp *lymphoma/ & 275110 \\
\hline 22 & *Brain Neoplasms/ & 76640 \\
\hline 23 & (cancer* or carcinoma? or tumour? or tumor? or malignan* or metasta*).ti. & 1562751 \\
\hline 24 & $\begin{array}{l}\text { ((breast or testic* or colon* or bowel or colorect* or colo-rect* or brain) adj3 } \\
\text { (cancer* or carcinoma? or tumour? or tumor? or malignan* or metasta*)).ti,ab. }\end{array}$ & 445150 \\
\hline 25 & (leukaemia or leukemia or lymphoma?).ti,ab. & 330877 \\
\hline 26 & *hiv infections/di & 7520 \\
\hline 27 & $\begin{array}{l}\text { ((hiv or human immunodeficiency virus?) adj3 (disclose? or disclosure or } \\
\text { diagnos* or prognos*)).ti,ab. }\end{array}$ & 11046 \\
\hline 28 & Hemorrhagic Fever, Ebola/ & 2784 \\
\hline 29 & ebola.ti,ab. & 4794 \\
\hline 30 & $\begin{array}{l}12 \text { or } 13 \text { or } 14 \text { or } 15 \text { or } 16 \text { or } 17 \text { or } 18 \text { or } 19 \text { or } 20 \text { or } 21 \text { or } 22 \text { or } 23 \text { or } 24 \text { or } 25 \text { or } \\
26 \text { or } 27 \text { or } 28 \text { or } 29\end{array}$ & 2278846 \\
\hline 31 & 11 and 30 & 1744 \\
\hline 32 & limit 31 to "reviews (maximizes specificity)" & 23 \\
\hline 33 & (Qualitative systematic review* or (systematic review and qualitative)).ti,ab. & 3131 \\
\hline 34 & (evidence synthesis or realist synthesis).ti,ab. & 2023 \\
\hline 35 & (Qualitative and synthesis).ti,ab. & 4232 \\
\hline 36 & (meta-synthesis* or meta synthesis* or metasynthesis).ti,ab. & 559 \\
\hline 37 & (meta-ethnograph* or metaethnograph* or meta ethnograph*).ti,ab. & 269 \\
\hline 38 & (meta-study or metastudy or meta study).ti,ab. & 65 \\
\hline 39 & (realist review? or realist synthesis).ti,ab. & 199 \\
\hline 40 & systematic review*.ti,ab. and qualitative research/ & 416 \\
\hline 41 & 33 or 34 or 35 or 36 or 37 or 38 or 39 or 40 & 8731 \\
\hline 42 & 31 and 41 & 4 \\
\hline 43 & 32 or 42 & 24 \\
\hline
\end{tabular}


Table 1: Studies concerning communication with children about life threatening illness in their parent

\begin{tabular}{|c|c|c|c|c|c|c|c|c|c|c|}
\hline Author & $\begin{array}{l}\text { Qualitative or } \\
\text { Quantitative }\end{array}$ & $\begin{array}{l}\text { Size } \\
\text { of } \\
\text { study } \\
\text { (n) }\end{array}$ & $\begin{array}{l}\text { Type of } \\
\text { participants }\end{array}$ & $\begin{array}{l}\text { Child age } \\
\text { range in } \\
\text { years(mean) }\end{array}$ & $\begin{array}{l}\text { Parental } \\
\text { diagnosis }\end{array}$ & $\begin{array}{l}\text { Method of } \\
\text { recruitment }\end{array}$ & $\begin{array}{l}\text { Method \& } \\
\text { measures }\end{array}$ & $\begin{array}{l}\text { How was } \\
\text { communication } \\
\text { assessed? }\end{array}$ & Results & Location \\
\hline $\begin{array}{l}\text { Armistead, } \\
\text { Tannenbaum } \\
\text { et al. } 2001^{47}\end{array}$ & $\begin{array}{l}\text { Mixed } \\
\text { methods }\end{array}$ & 174 & $\begin{array}{l}87 \text { HIV- } \\
\text { positive } \\
\text { mothers; } 87 \\
\text { children }\end{array}$ & 6-11 & HIV & HIV clinic & $\begin{array}{l}\text { Disclosure classed } \\
\text { as: disclosed or non- } \\
\text { disclosed (maternal } \\
\text { rating). Semi } \\
\text { structured } \\
\text { interviews (child } \\
\text { reaction to } \\
\text { disclosure). } \\
\text { Mothers: PSI, CBCL. } \\
\text { Child: CBCL, CDI }\end{array}$ & $\begin{array}{l}\text { Disclosure } \\
\text { status }\end{array}$ & $\begin{array}{l}\text { Less than } 30 \% \text { of mothers disclosed } \\
\text { to their children. Disclosure more } \\
\text { likely in families with lower incomes } \\
\& \text { mothers who reported being more } \\
\text { bothered by physical symptoms. } \\
\text { Higher rates of disclosure to girls \& to } \\
\text { older children. Disclosure unrelated } \\
\text { to internalising or externalising } \\
\text { problems }\end{array}$ & USA \\
\hline $\begin{array}{l}\text { Barnes, Kroll } \\
\text { et al. } 2000^{45} \text {, } \\
\text { Barnes, Kroll } \\
\text { et al. } 2002^{49}\end{array}$ & $\begin{array}{l}\text { Mixed } \\
\text { methods }\end{array}$ & 88 & $\begin{array}{l}32 \text { mothers; } \\
56 \text { children }\end{array}$ & $5-18$ & $\begin{array}{l}\text { Stage I or } \\
\text { II breast } \\
\text { cancer }\end{array}$ & $\begin{array}{l}\text { Mother's } \\
\text { medical team }\end{array}$ & $\begin{array}{l}\text { Semi structured } \\
\text { interviews (timing \& } \\
\text { extent of } \\
\text { communication } \\
\text { about diagnosis \& } \\
\text { treatment, reasons } \\
\text { \& barriers for } \\
\text { communication). } \\
\text { Total } \\
\text { communication } \\
\text { scores calculated } \\
\text { based on } \\
\text { categorisation of } \\
\text { interview responses }\end{array}$ & $\begin{array}{l}\text { Content } \\
\text { analysis \& total } \\
\text { communication } \\
\text { scores }\end{array}$ & $\begin{array}{l}\text { Mothers gave their children varying } \\
\text { levels of information at different } \\
\text { stages of the diagnostic/treatment } \\
\text { journey; } 70 \% \text { given information after } \\
\text { second outpatient visit when } \\
\text { diagnosis confirmed by biopsy. Older } \\
\text { children told earlier about parental } \\
\text { illness. Children of more educated } \\
\text { mothers given less information. Child } \\
\text { gender did not effect total } \\
\text { communication. Most common } \\
\text { reason for not communicating was } \\
\text { avoidance of children's questions, } \\
\text { particularly about death. Many } \\
\text { mothers wanted advice from HCP } \\
\text { about how to talk to their children } \\
\text { about illness }\end{array}$ & UK \\
\hline $\begin{array}{l}\text { Beale, } \\
\text { Sivesind et } \\
\text { al. 2004 }\end{array}$ & Qualitative & 28 & Children & $3-18$ & $\begin{array}{l}\text { Cancer } \\
\text { (locally } \\
\text { recurrent } \\
\text { or } \\
\text { metastati } \\
\text { c) } \\
\end{array}$ & $\begin{array}{l}\text { Parents' } \\
\text { medical team } \\
\& \text { palliative } \\
\text { care service }\end{array}$ & $\begin{array}{l}\text { Semi structured } \\
\text { interviews or play } \\
\text { based assessment } \\
\text { for ages 3-8 } \\
\text { (emotional response } \\
\text { to parental cancer) } \\
\end{array}$ & $\begin{array}{l}\text { Content } \\
\text { analysis }\end{array}$ & $\begin{array}{l}\text { Children with dying parents had } \\
\text { greater understanding of their } \\
\text { parent's illness than their parents } \\
\text { thought. Even small children were } \\
\text { aware of parent's medical condition } \\
\& \text { implications }\end{array}$ & USA \\
\hline $\begin{array}{l}\text { Bugge, } \\
\text { Helseth et al. } \\
2009^{76}\end{array}$ & Qualitative & 13 & $\begin{array}{l}6 \text { patients; } \\
7 \text { partners } \\
\& \text { ex } \\
\text { partners }\end{array}$ & 5-18 & $\begin{array}{l}\text { Incurable } \\
\text { cancer } \\
\text { (breast, } \\
\text { bowel, } \\
\text { brain, }\end{array}$ & $\begin{array}{l}\text { Part of The } \\
\text { Family } \\
\text { Support } \\
\text { Program }\end{array}$ & $\begin{array}{l}\text { In depth interviews } \\
\text { (experiences of } \\
\text { family illness and } \\
\text { Family Support } \\
\text { Program) }\end{array}$ & Kvale guidelines & $\begin{array}{l}\text { Parents concerned about harming } \\
\text { their children by not telling them in } \\
\text { the 'right' way or at the 'right time'. } \\
\text { Parents wanted guidance from, \& a } \\
\text { shared responsibility for their child's }\end{array}$ & Norway \\
\hline
\end{tabular}




\begin{tabular}{|c|c|c|c|c|c|c|c|c|c|c|}
\hline & & & & & $\begin{array}{l}\text { pancreas } \\
\text { ) }\end{array}$ & & & & $\begin{array}{l}\text { wellbeing, with HCP. Parents needed } \\
\text { reassurance \& validation about how } \\
\text { they had communicated their illness } \\
\text { with their children thus far. } \\
\text { Separated parents found it helpful to } \\
\text { have facilitated conversations in } \\
\text { order to support their mutual } \\
\text { children. Parents found it helpful to } \\
\text { have information about children's } \\
\text { normal reactions to such } \\
\text { circumstances to understand their } \\
\text { child's behaviour. Parents reported } \\
\text { the programme helped their children } \\
\text { talk more within the family about } \\
\text { how they were coping \& in voicing } \\
\text { the 'difficult questions' which might } \\
\text { otherwise be too difficult to raise }\end{array}$ & \\
\hline $\begin{array}{l}\text { Bylund- } \\
\text { Grenklo, } \\
\text { Kreicbergs et } \\
\text { al. } 2015^{15}\end{array}$ & Quantitative & 622 & $\begin{array}{l}\text { Bereaved } \\
\text { child }\end{array}$ & $\begin{array}{l}18-26 \\
\text { (age } 13-16 \text { at } \\
\text { time of } \\
\text { bereavement } \\
\text { ) }\end{array}$ & Cancer & $\begin{array}{l}\text { Population } \\
\text { based survey }\end{array}$ & $\begin{array}{l}\text { Swedish National } \\
\text { Causes of Death } \\
\text { Register \& Multi- } \\
\text { generational } \\
\text { Register used to } \\
\text { identify parents \& } \\
\text { children } \\
\text { respectively. Postal } \\
\text { questionnaire } \\
\text { developed by study } \\
\text { team (awareness of } \\
\text { parental death \& } \\
\text { extent of } \\
\text { communication with } \\
\text { dying parent) }\end{array}$ & Questionnaire & $\begin{array}{l}98 \% \text { reported teenage children } \\
\text { should be informed when the } \\
\text { parent's death was imminent, but } \\
\text { only } 59 \% \text { had been informed. Often } \\
\text { parent(s) and teenage children } \\
\text { pretended that the illness was not } \\
\text { that serious to avoid communication }\end{array}$ & Sweden \\
\hline $\begin{array}{l}\text { Christ and } \\
\text { Christ 2006 }\end{array}$ & Qualitative & 87 & Children & $3-11$ & Cancer & $\begin{array}{l}\text { Children of } \\
\text { participants } \\
\text { enrolled in a } \\
\text { parent } \\
\text { guidance } \\
\text { intervention } \\
\text { for families } \\
\text { beginning 3-6 } \\
\text { months pre } \\
\text { bereavement } \\
\& 14 \text { months } \\
\text { after parental } \\
\text { death }\end{array}$ & $\begin{array}{l}\text { Individual } \\
\text { interviews } 6 \text { months } \\
\text { before death } \\
\text { anticipated, at time } \\
\text { of parent's death, } \\
\text { and during } \\
\text { immediate post- } \\
\text { bereavement } \\
\text { period. Interviews } \\
\text { (experience of } \\
\text { parental illness, } \\
\text { death \& } \\
\text { bereavement) }\end{array}$ & $\begin{array}{l}\text { Content } \\
\text { analysis }\end{array}$ & $\begin{array}{l}\text { 3-5 year olds observe physical } \\
\text { manifestation of parent's illness but } \\
\text { cannot understand permanence of } \\
\text { death. Children need a concrete } \\
\text { description of what death means \& } \\
\text { caregivers should anticipate } \\
\text { children's' questions will be frequent } \\
\& \text { repetitive. } \\
\text { Authors recommend parents ensure } \\
\text { that children are adequately } \\
\text { supported when visiting sick parent; } \\
\text { uncontained parental grief \& distress } \\
\text { can be frightening for children. }\end{array}$ & USA \\
\hline
\end{tabular}




\begin{tabular}{|c|c|c|c|c|c|c|c|c|c|c|}
\hline & & & & & & & & & $\begin{array}{l}\text { 6-8 year olds need simple, concrete } \\
\text { information \& simple explanations } \\
\text { about parent's behaviour, } \\
\text { appearance, symptoms \& treatment } \\
\text { to avoid magical thinking. Children } \\
\text { may have variable awareness of } \\
\text { parent's imminent death \& are } \\
\text { sensitive to emotional state of } \\
\text { parents \& react accordingly. } \\
9-11 \text { year olds can use logical thinking } \\
\text { to understand cause \& effect, but still } \\
\text { require concrete explanations \& } \\
\text { sequenced information }\end{array}$ & \\
\hline $\begin{array}{l}\text { Christ, Siegel } \\
\text { et al. } 1993^{18}\end{array}$ & Qualitative & 87 & Children & $7-11$ & $\begin{array}{l}\text { Advance } \\
d / \text { termin } \\
\text { al cancer } \\
\text { with } \\
\text { expected } \\
\text { survival } \\
\text { time of } 6 \\
\text { months }\end{array}$ & $\begin{array}{l}\text { Cancer } \\
\text { Centre }\end{array}$ & $\begin{array}{l}\text { Individual } \\
\text { interviews } \\
\text { (experience of } \\
\text { parental illness \& } \\
\text { death) with children } \\
\text { before parent had } \\
\text { died }\end{array}$ & $\begin{array}{l}\text { Content } \\
\text { analysis }\end{array}$ & $\begin{array}{l}\text { Common fears \& concerns; impact of } \\
\text { illness \& side effects on children, fear } \\
\text { of parent's death. Children's } \\
\text { developmental understanding of } \\
\text { illness \& death can lead to } \\
\text { misunderstandings of the cause of } \\
\text { illness \& visible symptoms in the } \\
\text { absence of concrete information from } \\
\text { parents }\end{array}$ & USA \\
\hline $\begin{array}{l}\text { Chowns } \\
2013^{73}\end{array}$ & Qualitative & 9 & Children & $7-15$ & Cancer & $\begin{array}{l}\text { Social worker } \\
\text { in palliative } \\
\text { care team }\end{array}$ & $\begin{array}{l}\text { Participant } \\
\text { researched their } \\
\text { own lived } \\
\text { experiences by } \\
\text { making a group DVD }\end{array}$ & $\begin{array}{l}\text { Content } \\
\text { analysis }\end{array}$ & $\begin{array}{l}\text { Adolescents' experience a sense of } \\
\text { isolation, uncertainty about the } \\
\text { future } \& \text { need support in facing the } \\
\text { anticipated difficulties ahead, rather } \\
\text { than protection from them. They } \\
\text { want the truth about their parent's } \\
\text { condition \& comprehensive, timely } \\
\text { information }\end{array}$ & UK \\
\hline $\begin{array}{l}\text { Davey, } \\
\text { Tubbs et al. } \\
2011^{75}\end{array}$ & Qualitative & 12 & Children & $11-18$ & $\begin{array}{l}\text { Breast } \\
\text { cancer }\end{array}$ & $\begin{array}{l}\text { Parents' } \\
\text { medical team }\end{array}$ & $\begin{array}{l}\text { Three focus groups } \\
\text { with semi- } \\
\text { structured } \\
\text { discussion format } \\
\text { (experience of } \\
\text { parental diagnosis, } \\
\text { treatment, } \\
\text { relationship \& } \\
\text { emotional response) }\end{array}$ & $\begin{array}{l}\text { Content } \\
\text { analysis }\end{array}$ & $\begin{array}{l}\text { Children found it hard to share } \\
\text { feelings with friends who had not } \\
\text { experienced parental cancer. } \\
\text { Described feeling overlooked \& } \\
\text { unappreciated by their parent's } \\
\text { medical team. Keenly aware of their } \\
\text { parents' treatment regimen \& side } \\
\text { effects. Wanted a teen group around } \\
\text { the time of diagnosis \& treatment. } \\
\text { Preference to talk to young people, } \\
\text { but acknowledged some incentive } \\
\text { might be necessary to encourage } \\
\text { them to attend the group initially. }\end{array}$ & USA \\
\hline
\end{tabular}




\begin{tabular}{|c|c|c|c|c|c|c|c|c|c|c|}
\hline $\begin{array}{l}\text { De Baets, } \\
\text { Sifovo et al. } \\
2008^{63}\end{array}$ & Quantitative & 195 & $\begin{array}{l}64 \mathrm{HCPs} ; \\
131 \\
\text { community } \\
\text { members }\end{array}$ & $0-12$ & $\begin{array}{l}\text { Communi } \\
\text { ty sample } \\
\text { consideri } \\
\text { ng } \\
\text { factors } \\
\text { influenci } \\
\text { ng HIV } \\
\text { disclosur } \\
\text { e in } \\
\text { hypotheti } \\
\text { cal } \\
\text { scenarios }\end{array}$ & $\begin{array}{l}\text { Primary } \\
\text { healthcare } \\
\text { centres (not } \\
\text { specifically } \\
\text { parents') }\end{array}$ & $\begin{array}{l}\text { Disclosure classed } \\
\text { as: Full disclosure } \\
\text { (to have all } \\
\text { information); Partial } \\
\text { disclosure (being } \\
\text { told there is a } \\
\text { disease, but not } \\
\text { specifically HIV); } \\
\text { No disclosure (being } \\
\text { told nothing) } \\
32 \text { item } \\
\text { questionnaire } \\
\text { (related to } \\
\text { disclosure) } \\
\text { developed by } \\
\text { researchers plus } 7 \\
\text { questions specific } \\
\text { for HCP about their } \\
\text { confidence in } \\
\text { assisting with } \\
\text { disclosure }\end{array}$ & $\begin{array}{l}\text { Descriptive } \\
\text { analysis }\end{array}$ & $\begin{array}{l}\text { For a hypothetical situation, } 63 \% \text { of } \\
\text { participants expressed the need to } \\
\text { give a child some information about } \\
\text { the parent's HIV status, with } 69 \% \\
\text { opting for full disclosure to children } \\
\text { older than } 11 \text { years. HCPs opted for } \\
\text { partial \& full disclosure at significantly } \\
\text { younger ages than community } \\
\text { members. Higher levels of education } \\
\text { associated with full disclosure at a } \\
\text { significantly younger age. } \\
\text { Up to a third would prefer to initiate } \\
\text { conversations about HIV disclosure \& } \\
\text { grief with own children without } \\
\text { assistance. However over half would } \\
\text { prefer to have involvement from a } \\
\text { health worker \& } 40-50 \% \text { have help } \\
\text { from a family member (most } \\
\text { commonly father's sister \& } \\
\text { grandmother, rather than partner) }\end{array}$ & $\begin{array}{l}\text { Zimbab } \\
\text { we }\end{array}$ \\
\hline $\begin{array}{l}\text { Edwards, } \\
\text { Watson et } \\
\text { al. } 2008^{28}\end{array}$ & Quantitative & 109 & $\begin{array}{l}56 \\
\text { adolescents } \\
; 53 \\
\text { mothers }\end{array}$ & 11-17 & $\begin{array}{l}\text { Stage I/II } \\
\text { breast } \\
\text { cancer }\end{array}$ & $\begin{array}{l}\text { Single cancer } \\
\text { centre }\end{array}$ & $\begin{array}{l}\text { Adolescent: YSR of } \\
\text { CBCL, CHQ-MH, C- } \\
\text { IES, FAD, FES. } \\
\text { Mothers: BDI, SF8 } \\
\text { version of Medical } \\
\text { Outcomes Health } \\
\text { Survey }\end{array}$ & FAD & $\begin{array}{l}\text { Poor family functioning \& } \\
\text { cohesiveness associated with } \\
\text { adolescent emotional \& behavioural } \\
\text { problems. Poor family cohesiveness } \\
\text { associated with increased stress } \\
\text { responses. Internalising \& } \\
\text { externalising behaviour significantly } \\
\text { associated with poor communication } \\
\text { \& poor affective responses }\end{array}$ & UK \\
\hline $\begin{array}{l}\text { Ellis, Dowrick } \\
\text { et al. } 2013^{16}\end{array}$ & Qualitative & 33 & $\begin{array}{l}\text { Adults who } \\
\text { had } \\
\text { experienced } \\
\text { the death of } \\
\text { a parent } \\
\text { before the } \\
\text { age of } 18\end{array}$ & $\begin{array}{l}13 \mathrm{~m}-17 \mathrm{yrs} \text { at } \\
\text { time of death } \\
20-80 \text { at time } \\
\text { of study }\end{array}$ & $\begin{array}{l}\text { Mixed } \\
\text { group } \\
\text { including } \\
\text { cancer, } \\
\text { heart } \\
\text { attack, } \\
\text { stroke \& } \\
\text { trauma }\end{array}$ & $\begin{array}{l}\text { Community } \\
\text { recruitment } \\
\text { through } \\
\text { media }\end{array}$ & $\begin{array}{l}\text { Participant chose to } \\
\text { write their } \\
\text { experience or take } \\
\text { part in an in depth } \\
\text { narrative interviews } \\
\text { (impact of parental } \\
\text { death) }\end{array}$ & $\begin{array}{l}\text { Narrative } \\
\text { analysis }\end{array}$ & $\begin{array}{l}\text { Distress compounded when children } \\
\text { not given accurate information. Some } \\
\text { described "implicit rules" for not } \\
\text { speaking about the deceased parent } \\
\text { had a negative impact on family } \\
\text { functioning }\end{array}$ & UK \\
\hline $\begin{array}{l}\text { Ernst, } \\
\text { Beierlein et } \\
\text { al. } 2013^{65}\end{array}$ & Quantitative & 1809 & $\begin{array}{l}\text { Adult } \\
\text { patients } \\
\text { diagnosed } \\
\text { no more } \\
\text { than } 6 \text { yrs }\end{array}$ & $<22$ & Cancer & $\begin{array}{l}\text { Cancer } \\
\text { registries }\end{array}$ & $\begin{array}{l}\text { HADS, OSSS, } \\
\text { FAD,SF-8, Likert } \\
\text { scales regarding use } \\
\text { of psychosocial } \\
\text { support }\end{array}$ & Not measured & $\begin{array}{l}73 \% \text { of cancer patients with children } \\
\text { wanted either information (about } \\
\text { how to talk to their child about } \\
\text { cancer, common emotional responses } \\
\text { of children to such news) or active } \\
\text { psychosocial support regarding issues } \\
\text { pertaining to parental cancer. } 9 \% \text { of }\end{array}$ & German \\
\hline
\end{tabular}




\begin{tabular}{|c|c|c|c|c|c|c|c|c|c|c|}
\hline & & & & & & & & & $\begin{array}{l}\text { participants had accessed family or } \\
\text { child-centred support; rates of } \\
\text { satisfaction with this input were high. }\end{array}$ & \\
\hline $\begin{array}{l}\text { Forrest, } \\
\text { Plumb et al. } \\
2006^{14}\end{array}$ & Qualitative & 68 & $\begin{array}{l}37 \text { mothers; } \\
31 \text { children }\end{array}$ & $6-18$ & $\begin{array}{l}\text { New } \\
\text { diagnosis } \\
\text { of stage } \\
\text { I-Illa } \\
\text { breast } \\
\text { cancer }\end{array}$ & $\begin{array}{l}\text { Single cancer } \\
\text { centre }\end{array}$ & $\begin{array}{l}\text { Individual semi } \\
\text { structured } \\
\text { interviews (child } \\
\text { awareness, } \\
\text { understanding, } \\
\text { reaction to } \\
\text { diagnosis \& } \\
\text { treatment, } \\
\text { informational } \\
\text { needs) }\end{array}$ & $\begin{array}{l}\text { Thematic } \\
\text { analysis }\end{array}$ & $\begin{array}{l}\text { Even the youngest children were } \\
\text { aware of cancer as a life threatening } \\
\text { illness. Children suspected something } \\
\text { was wrong before they were told the } \\
\text { diagnosis. Parents sometimes } \\
\text { misunderstood their children's } \\
\text { reactions \& underestimated the } \\
\text { emotional impact of the illness. } \\
\text { Parents did not always recognise the } \\
\text { child's need for preparation \& age } \\
\text { appropriate information about the } \\
\text { illness, treatment \& side effects }\end{array}$ & UK \\
\hline $\begin{array}{l}\text { Forrest, } \\
\text { Plumb et al. } \\
2009^{21}\end{array}$ & Qualitative & 57 & $\begin{array}{l}26 \text { non- } \\
\text { affected } \\
\text { fathers; } 31 \\
\text { children }\end{array}$ & $6-18$ & $\begin{array}{l}\text { Maternal } \\
\text { new } \\
\text { diagnosis } \\
\text { of stage } \\
\text { I-Illa } \\
\text { breast } \\
\text { cancer. } \\
\text { Child } \\
\text { interview } \\
\text { s 3-6 } \\
\text { months } \\
\text { after } \\
\text { diagnosis }\end{array}$ & $\begin{array}{l}\text { Single cancer } \\
\text { centre }\end{array}$ & $\begin{array}{l}\text { Individual semi } \\
\text { structured } \\
\text { interviews (child } \\
\text { awareness, } \\
\text { understanding, } \\
\text { reaction to } \\
\text { diagnosis \& } \\
\text { treatment, } \\
\text { informational } \\
\text { needs). Child } \\
\text { interviews } \\
\text { sometimes included } \\
\text { drawing \& play }\end{array}$ & $\begin{array}{l}\text { Thematic } \\
\text { analysis }\end{array}$ & $\begin{array}{l}\text { Fathers wanted to protect \& reassure } \\
\text { their children but felt this was } \\
\text { hindered by insufficient information } \\
\text { about breast cancer. Fathers did not } \\
\text { always recognise the extent of their } \\
\text { child's distress or misinterpreted } \\
\text { signs of distress. Children were aware } \\
\text { of their fathers' distress \& wanted to } \\
\text { protect him. }\end{array}$ & UK \\
\hline $\begin{array}{l}\text { Giesbers, de } \\
\text { Leeuw et al. } \\
2010^{50}\end{array}$ & Qualitative & 137 & $\begin{array}{l}129 \\
\text { children; } 8 \\
\text { adults }\end{array}$ & $\begin{array}{l}8-46 \\
(15.3, \text { median } \\
14)\end{array}$ & Cancer & $\begin{array}{l}\text { Users of } \\
\text { website for } \\
\text { children of } \\
\text { parents with } \\
\text { cancer }\end{array}$ & $\begin{array}{l}\text { Analysis of forum } \\
\text { discussions on } \\
\text { Dutch website } \\
\text { (www.kankerspoken } \\
\text {.nl) over a } 3 \text { month } \\
\text { time period }\end{array}$ & $\begin{array}{l}\text { Content } \\
\text { analysis }\end{array}$ & $\begin{array}{l}\text { Young people used website to share } \\
\text { personal experiences, provide } \\
\text { encouragement/support or seek } \\
\text { information \& advice. Children } \\
\text { regularly faced emotional problems \& } \\
\text { experienced a lack of understanding } \\
\text { \& communication in their direct } \\
\text { environment }\end{array}$ & $\begin{array}{l}\text { Netherla } \\
\text { nds }\end{array}$ \\
\hline $\begin{array}{l}\text { Harris and } \\
\text { Zakowski } \\
2003^{27}\end{array}$ & Quantitative & 50 & Adolescents & $12-19(15.7)$ & $\begin{array}{l}\text { Cancer } \\
\text { diagnose } \\
\text { d within } \\
\text { last } 5 \\
\text { years }\end{array}$ & $\begin{array}{l}\text { Cancer } \\
\text { support } \\
\text { groups \& } \\
\text { oncology } \\
\text { clinics in } \\
\text { three US } \\
\text { states }\end{array}$ & $\begin{array}{l}\text { Telephone } \\
\text { completion of CDI, } \\
\text { RCMAS, IES, PTSD } \\
\text { Checklist-civilian } \\
\text { version, FES, PRS }\end{array}$ & FES & $\begin{array}{l}\text { No significant differences between } \\
\text { groups in symptoms of depression or } \\
\text { anxiety. Positive family relationships } \\
\text { associated with lower anxiety \& } \\
\text { depression symptoms in adolescents } \\
\text { of parents with cancer. Analysis for } \\
\text { both adolescent groups found } \\
\text { expressiveness is mediator between } \\
\text { family cohesion \& anxiety. }\end{array}$ & USA \\
\hline
\end{tabular}




\begin{tabular}{|c|c|c|c|c|c|c|c|c|c|c|}
\hline Harris $1991^{25}$ & $\begin{array}{l}\text { Mixed } \\
\text { methods }\end{array}$ & 11 & $\begin{array}{l}\text { Bereaved } \\
\text { adolescents }\end{array}$ & 13-18 & $\begin{array}{l}\text { Terminal } \\
\text { illness, } \\
\text { suicide or } \\
\text { sudden \& } \\
\text { unexpect } \\
\text { ed } \\
\text { (medical } \\
\text { emergen } \\
\text { cy } \\
\text { related } \\
\text { to } \\
\text { underlyin } \\
\text { g } \\
\text { condition } \\
\text { ) }\end{array}$ & $\begin{array}{l}\text { Community } \\
\text { resources } \\
\text { (most via } \\
\text { school } \\
\text { counsellors } \\
\text { responding to } \\
\text { project } \\
\text { announceme } \\
\text { nts) }\end{array}$ & $\begin{array}{l}\text { Adolescent followed } \\
\text { through the year } \\
\text { following parental } \\
\text { death using semi } \\
\text { structured } \\
\text { interviews, DISC } \\
\text { (experience of } \\
\text { parental death, } \\
\text { relationship with } \\
\text { deceased, } \\
\text { emotional } \\
\text { response). Parent } \\
\text { interviews. } \\
\text { Adolescent: CDI, } \\
\text { YSR, IES. Teacher: } \\
\text { CBCL. } \\
\text { Parent: IES, BDI. } \\
\text { Completed at } \\
\text { recruitment, } 7 \& 13 \\
\text { months after } \\
\text { bereavement }\end{array}$ & $\begin{array}{l}\text { Descriptive } \\
\text { analysis }\end{array}$ & $\begin{array}{l}\text { For some participants the cause of } \\
\text { death remained unclear as } \\
\text { information given had been } \\
\text { insufficient or distorted. These } \\
\text { misunderstandings led to feelings of } \\
\text { regret \& guilt about their possible } \\
\text { role in causing or being unable to } \\
\text { prevent the death. } \\
\text { Most adolescents believed that } \\
\text { emotional expression or discussions } \\
\text { of death were unacceptable or } \\
\text { potentially overwhelming for their } \\
\text { friends }\end{array}$ & USA \\
\hline $\begin{array}{l}\text { Helseth and } \\
\text { Ulfsaet } \\
2005^{59}\end{array}$ & Qualitative & 18 & $\begin{array}{l}\text { Parents } \\
\text { (patients \& } \\
\text { partners) }\end{array}$ & $\begin{array}{l}4 \text { months - } \\
17 \mathrm{yrs}\end{array}$ & $\begin{array}{l}\text { Cancer: } \\
\text { breast, } \\
\text { colorecta } \\
\text { l, } \\
\text { melanom } \\
\text { a, } \\
\text { lymphom } \\
\text { a }\end{array}$ & $\begin{array}{l}\text { Parent's } \\
\text { medical team }\end{array}$ & $\begin{array}{l}\text { Individual in depth } \\
\text { interviews } \\
\text { (children's reactions } \\
\& \text { needs, parental } \\
\text { experiences \& } \\
\text { needs) with ill \& } \\
\text { healthy parent on } 2 \\
\text { occasions }\end{array}$ & Kvale guidelines & $\begin{array}{l}\text { Parents reported best way to manage } \\
\text { illness was to be open about } \\
\text { situation. Parents expressed strong } \\
\text { desire for advice about how to talk to } \\
\text { their children about illness \& felt this } \\
\text { type of support was absent. Talking } \\
\text { about the possibility of death was a } \\
\text { particular area of concern for parents }\end{array}$ & Norway \\
\hline $\begin{array}{l}\text { Huizinga, } \\
\text { Visser et al. } \\
2005^{30}\end{array}$ & Quantitative & 284 & $\begin{array}{l}\text { Children \& } \\
\text { adolescents }\end{array}$ & $\begin{array}{l}11-18 \\
\& 19-23\end{array}$ & $\begin{array}{l}\text { Cancer } \\
\text { diagnose } \\
\text { d 1-5 } \\
\text { years } \\
\text { prior to } \\
\text { study } \\
\text { (breast, } \\
\text { gynaecol } \\
\text { ogical, } \\
\text { skin, } \\
\text { haematol } \\
\text { ogical } \\
\text { malignan } \\
\text { cies) }\end{array}$ & $\begin{array}{l}\text { Single cancer } \\
\text { centre }\end{array}$ & $\begin{array}{l}\text { Dutch IES, Dutch } \\
\text { YSR, STAI-CH }\end{array}$ & Not measured & $\begin{array}{l}21 \% \text { of sons \& } 35 \% \text { of daughters } \\
\text { reported clinically elevated stress } \\
\text { response symptoms (IES). Daughters, } \\
\text { particularly those whose mothers } \\
\text { were ill, reported significantly more } \\
\text { intrusion } \& \text { avoidance symptoms } \\
\text { compared to sons. Daughters worry } \\
\text { more about their own chances of } \\
\text { getting cancer ( } 2 / 3 \text { of patients in } \\
\text { study had female-specific cancer). } \\
\text { Perceptions of seriousness of disease } \\
\text { related to stress response for } \\
\text { daughters, but not for sons }\end{array}$ & $\begin{array}{l}\text { Netherla } \\
\text { nds }\end{array}$ \\
\hline
\end{tabular}




\begin{tabular}{|c|c|c|c|c|c|c|c|c|c|c|}
\hline $\begin{array}{l}\text { Huizinga, } \\
\text { Visser et al. } \\
2005^{31}\end{array}$ & Quantitative & 212 & $\begin{array}{l}\text { Children \& } \\
\text { adolescents }\end{array}$ & $11-18$ & $\begin{array}{l}\text { Cancer } \\
\text { diagnose } \\
\text { d 1-5 } \\
\text { years } \\
\text { prior to } \\
\text { study } \\
\text { (breast, } \\
\text { gynaecol } \\
\text { ogical, } \\
\text { skin, } \\
\text { haematol } \\
\text { ogical } \\
\text { malignan } \\
\text { cies) }\end{array}$ & $\begin{array}{l}\text { Single cancer } \\
\text { centre }\end{array}$ & Dutch IES, PACS & PACS & $\begin{array}{l}\text { Adolescents communicated less } \\
\text { openly with mothers who had cancer, } \\
\text { relative to population reference } \\
\text { group data. Problem communication } \\
\text { (with both parents) was related to } \\
\text { PTSS in sons \& daughters. Parents } \\
\text { receiving more intensive treatment } \\
\text { associated with more problem } \\
\text { communication for sons \& less open } \\
\text { communication for daughters }\end{array}$ & $\begin{array}{l}\text { Netherla } \\
\text { nds }\end{array}$ \\
\hline $\begin{array}{l}\text { Kennedy and } \\
\text { Lloyd- } \\
\text { Williams } \\
2009^{24}\end{array}$ & Qualitative & 28 & $\begin{array}{l}11 \text { children; } \\
10 \text { ill } \\
\text { parents; } 7 \\
\text { carers }\end{array}$ & $7-18$ & $\begin{array}{l}\text { Advance } \\
\text { d cancer }\end{array}$ & $\begin{array}{l}\text { Parents' } \\
\text { cancer } \\
\text { centre, } \\
\text { oncology } \\
\text { team, hospice } \\
\text { or GP }\end{array}$ & $\begin{array}{l}\text { Semi structured } \\
\text { interviews (to } \\
\text { identify } \\
\text { communication \& } \\
\text { informational needs } \\
\text { of children when } \\
\text { parent has cancer). } \\
\text { Children chose to be } \\
\text { interviewed alone } \\
\text { or with } \\
\text { parents/siblings }\end{array}$ & $\begin{array}{l}\text { Constructionist } \\
\text { grounded } \\
\text { theory } \\
\text { approach }\end{array}$ & $\begin{array}{l}\text { All children wanted honest } \\
\text { information about their parent's } \\
\text { health \& treatment; variation with } \\
\text { some wanting total honesty \& others } \\
\text { wanting parents to filter the } \\
\text { information according to what they } \\
\text { felt able to deal with. Wanted } \\
\text { information from a range of sources, } \\
\text { including parents, HCP, books, } \\
\text { leaflets \& online. Concerns about not } \\
\text { wanting to upset parents by asking } \\
\text { direct questions, lack of access to } \\
\text { professionals \& age appropriate } \\
\text { information. Parents identified } \\
\text { informing children of their diagnosis } \\
\& \text { coping with their children's } \\
\text { questions as main challenge. Parents } \\
\text { did not want to keep secrets \& } \\
\text { wanted to prepare their children. } \\
\text { Reasons for not telling; causing their } \\
\text { child distress or not knowing how to } \\
\text { tell them }\end{array}$ & UK \\
\hline $\begin{array}{l}\text { Kristjanson, } \\
\text { Chalmers et } \\
\text { al. } 2004^{22}\end{array}$ & Qualitative & 31 & Adolescents & $\begin{array}{l}12-20 \text { (age at } \\
\text { diagnosis } \\
<12-18 \text { ) }\end{array}$ & $\begin{array}{l}\text { Breast } \\
\text { cancer; } \\
\text { recently } \\
\text { diagnose } \\
\text { d, stages } \\
1-4, \\
\text { remission } \\
\& \\
\text { terminal }\end{array}$ & $\begin{array}{l}\text { Purposeful } \\
\text { sampling. } \\
\text { Cancer } \\
\text { centre, } \\
\text { palliative care } \\
\text { programme, } \\
\text { hospital- } \\
\text { based } \\
\text { support } \\
\text { group for }\end{array}$ & $\begin{array}{l}\text { Individual semi } \\
\text { structured } \\
\text { interviews } \\
\text { (experience of } \\
\text { parental illness, } \\
\text { perception of } \\
\text { support \& helpful } \\
\text { information) } \\
\text { communication }\end{array}$ & $\begin{array}{l}\text { Constant } \\
\text { comparison } \\
\text { techniques \& } \\
\text { FAD }\end{array}$ & $\begin{array}{l}\text { Most salient information adolescents } \\
\text { wanted was whether their mother } \\
\text { was going to survive. Wanted } \\
\text { information about the seriousness of } \\
\text { the illness, potential side effects, } \\
\text { medical facts, how to help their } \\
\text { mother, normal feelings for mothers } \\
\& \text { young people. Emphasised } \\
\text { importance of individually tailored } \\
\text { information. Benefitted from time }\end{array}$ & Canada \\
\hline
\end{tabular}




\begin{tabular}{|c|c|c|c|c|c|c|c|c|c|c|}
\hline & & & & & & $\begin{array}{l}\text { children } \\
\text { whose } \\
\text { parents had } \\
\text { cancer }\end{array}$ & $\begin{array}{l}\text { subscale of FAD. } \\
\text { Two focus groups }\end{array}$ & & $\begin{array}{l}\text { with HCP to provide facts \& follow up } \\
\text { information, but difficult to access. } \\
\text { Information conveyed in private } \\
\text { judged easier to understand. Family } \\
\text { members sometimes helpful as } \\
\text { information interpreters but } \\
\text { adolescents felt their parent's } \\
\text { management of information could be } \\
\text { too controlling \& protective }\end{array}$ & \\
\hline $\begin{array}{l}\text { Lee and } \\
\text { Rotheram- } \\
\text { Borus } 2002^{35}\end{array}$ & Quantitative & 696 & $\begin{array}{l}301 \\
\text { parents; } \\
395 \\
\text { adolescents }\end{array}$ & 11-18 & HIV & $\begin{array}{l}\text { HIV social } \\
\text { welfare } \\
\text { services }\end{array}$ & $\begin{array}{l}5 \text { year longitudinal } \\
\text { study. Disclosure } \\
\text { classed as: not } \\
\text { having occurred (0), } \\
\text { if } \\
\text { parents told } \\
\text { nothing, that they } \\
\text { were ill, or } \\
\text { chronically } \\
\text { ill; or as having } \\
\text { occurred (1), if } \\
\text { parents disclosed an } \\
\text { HIV or AIDS } \\
\text { diagnosis, or that } \\
\text { they were dying. } \\
\text { Parent: BSI, RSES, } \\
\text { family stressors \& } \\
\text { life events, social } \\
\text { support, coping } \\
\text { styles, perceived } \\
\text { stigma. } \\
\text { Adolescent: RSES, } \\
\text { BSI, PBI }\end{array}$ & $\begin{array}{l}\text { Disclosure } \\
\text { status }\end{array}$ & $\begin{array}{l}\text { Disclosure more likely to older } \\
\text { children. Mothers disclosed earlier } \\
\text { than fathers \& more often to } \\
\text { daughters than to sons. Disclosure } \\
\text { more common among parents with } \\
\text { poorer health, larger social networks } \\
\text { \& those who perceived child } \\
\text { experiencing more HIV-related } \\
\text { stigma. Following disclosure, } \\
\text { adolescents report more problem } \\
\text { behaviours in negative family events. } \\
\text { Parents perceive their children } \\
\text { experience HIV-related stigma } \\
\text { following disclosure }\end{array}$ & USA \\
\hline $\begin{array}{l}\text { Letteney and } \\
\text { LaPorte } \\
2004^{51}\end{array}$ & Quantitative & 88 & Mothers & $5-18$ & HIV & $\begin{array}{l}\text { HIV } \\
\text { Outpatient } \\
\text { clinic }\end{array}$ & $\begin{array}{l}\text { Disclosure classed } \\
\text { as: } 1=I \text { have } \\
\text { disclosed my HIV } \\
\text { status to at least } \\
\text { one of my children; } \\
2=I \text { am in the } \\
\text { process of disclosing } \\
\text { my HIV status; } 3=1 \\
\text { have } \\
\text { not disclosed my } \\
\text { HIV status. } \\
\text { PSS, DDM }\end{array}$ & $\begin{array}{l}\text { Disclosure } \\
\text { status }\end{array}$ & $\begin{array}{l}\text { No differences in physical or } \\
\text { psychological distress between } \\
\text { disclosure groups. No differences in } \\
\text { marital status, race, religion \& } \\
\text { employment between mothers who } \\
\text { had \& had not disclosed HIV status. } \\
\text { Mothers who disclosed HIV status } \\
\text { had fewer perceptions of HIV-related } \\
\text { stigma, more social support \& } \\
\text { managed HIV-related stigma with } \\
\text { strategies other than concealment. } \\
\text { Mothers who had not disclosed more } \\
\text { likely to feel devalued \& } \\
\text { discriminated against as result of HIV- }\end{array}$ & USA \\
\hline
\end{tabular}




\begin{tabular}{|c|c|c|c|c|c|c|c|c|c|c|}
\hline & & & & & & & & & $\begin{array}{l}\text { positive status \& to use secrecy to } \\
\text { manage perceived stigma }\end{array}$ & \\
\hline $\begin{array}{l}\text { Maynard, } \\
\text { Patterson et } \\
\text { al. } 2013^{58}\end{array}$ & Qualitative & 15 & $\begin{array}{l}\text { Young } \\
\text { people }\end{array}$ & $14-18$ (15.9) & $\begin{array}{l}\text { Non } \\
\text { terminal } \\
\text { cancer } \\
\text { diagnose } \\
d \text { within } \\
\text { last } 5 \\
\text { years } \\
\text { (breast, } \\
\text { mouth \& } \\
\text { throat, } \\
\text { leukaemi } \\
\text { a, brain } \\
\& \\
\text { stomach) }\end{array}$ & $\begin{array}{l}\text { Charity or } \\
\text { Voluntary } \\
\text { organisation }\end{array}$ & $\begin{array}{l}\text { Semi structured } \\
\text { interviews } \\
\text { (experience of } \\
\text { parental diagnosis, } \\
\text { emotional needs, } \\
\text { parental support \& } \\
\text { understanding of } \\
\text { their experience) }\end{array}$ & $\begin{array}{l}\text { Phenomenologi } \\
\text { cal thematic } \\
\text { data analysis }\end{array}$ & $\begin{array}{l}\text { Children gauged how much they } \\
\text { should worry on their parents' } \\
\text { behaviour \& used parents as role } \\
\text { models for what behaviour was } \\
\text { appropriate (e.g. using humour). } \\
\text { Wanted parents to be available to } \\
\text { talk \& answer questions about the } \\
\text { diagnosis, treatment \& how they } \\
\text { were coping. Felt guilty about talking } \\
\text { to parents about their feelings, but } \\
\text { being invited to talk by parents } \\
\text { alleviated guilt. Wanted measured } \\
\text { information so not overwhelming. } \\
\text { Considerable variation in preferences } \\
\text { for level of detail \& volume of } \\
\text { information }\end{array}$ & Australia \\
\hline $\begin{array}{l}\text { Murphy, } \\
\text { Steers et al. } \\
2001^{26}\end{array}$ & Quantitative & 270 & $\begin{array}{l}135 \\
\text { mothers; } \\
135 \\
\text { children }\end{array}$ & $6-11(8.47)$ & HIV & HIV clinics & $\begin{array}{l}\text { Disclosure classed } \\
\text { as: (a) } \\
\text { nondisclosure } \\
\text { (mothers whose } \\
\text { children knew } \\
\text { nothing } \\
\text { of their illness or } \\
\text { serostatus); (b) } \\
\text { maternal disclosure } \\
\text { (mothers who had } \\
\text { told their children } \\
\text { personally about } \\
\text { their serostatus); (c) } \\
\text { other disclosure } \\
\text { (children } \\
\text { who knew that their } \\
\text { mothers were ill or } \\
\text { chronically } \\
\text { ill and children who } \\
\text { knew that their } \\
\text { mother had } \\
\text { HIV/AIDS but were } \\
\text { informed by } \\
\text { someone other than } \\
\text { the mother). } \\
\text { Semi structured } \\
\text { interviews. }\end{array}$ & $\begin{array}{l}\text { Disclosure } \\
\text { status }\end{array}$ & $\begin{array}{l}\text { Maternal disclosure rate of } 30 \% \text {. } \\
\text { Reasons for non-disclosure; child too } \\
\text { young to understand, concern child } \\
\text { would disclose to others, not knowing } \\
\text { how to disclose, concern child would } \\
\text { respond negatively to disclosure or } \\
\text { lose respect for parent. Mothers who } \\
\text { had disclosed status reported higher } \\
\text { levels of social support relative to } \\
\text { those who had not disclosed. } \\
\text { Children of mothers who had } \\
\text { disclosed had lower levels of } \\
\text { aggressiveness \& negative self- } \\
\text { esteem relative to the non-disclosure } \\
\text { group }\end{array}$ & USA \\
\hline
\end{tabular}




\begin{tabular}{|c|c|c|c|c|c|c|c|c|c|c|}
\hline & & & & & & & $\begin{array}{l}\text { Mother: HDI, Family } \\
\text { Functioning (2 } \\
\text { subscales), ASSIS, } \\
\text { CBCL. } \\
\text { Child: CDI, HSC, } \\
\text { RCMAS }\end{array}$ & & & \\
\hline $\begin{array}{l}\text { Murphy, } \\
\text { Roberts et } \\
\text { al. } 2003^{56}\end{array}$ & Qualitative & 47 & $\begin{array}{l}\text { Mothers } \\
\text { who had } \\
\text { disclosed to } \\
\text { their } \\
\text { children }\end{array}$ & $6-11$ & HIV & $\begin{array}{l}\text { Participants } \\
\text { enrolled in } \\
\text { PACT } \\
\text { (Parents and } \\
\text { children } \\
\text { Coping } \\
\text { Together) } \\
\text { study }\end{array}$ & $\begin{array}{l}\text { Individual semi } \\
\text { structured } \\
\text { interviews (process } \\
\text { of disclosure \& } \\
\text { reflections) }\end{array}$ & $\begin{array}{l}\text { Grounded } \\
\text { theory } \\
\text { approach }\end{array}$ & $\begin{array}{l}\text { Majority of mothers did not regret } \\
\text { disclosure to their children. One third } \\
\text { of mothers regretted disclosure; } \\
\text { regrets categorised into } 5 \text { themes: } \\
\text { lack of preparation (in terms of timing } \\
\text { or planning what to say or when to } \\
\text { disclose), timing of disclosure (in } \\
\text { relation to child's age, maternal } \\
\text { health \& concurrent psychosocial } \\
\text { stressors), context of disclosure } \\
\text { (pertaining to maternal mood), } \\
\text { content of disclosure, impact of } \\
\text { disclosure on child \& desire for } \\
\text { professional support for their child }\end{array}$ & USA \\
\hline $\begin{array}{l}\text { Nam, } \\
\text { Fielding et } \\
\text { al. } 2009^{10}\end{array}$ & Qualitative & 61 & $\begin{array}{l}21 \text { parents } \\
\text { on ART; } 40 \\
\text { children } \\
\text { (subset of } \\
24 \\
\text { analysed) }\end{array}$ & $5-18$ & HIV & $\begin{array}{l}\text { Infectious } \\
\text { Diseases Care } \\
\text { Centre (IDCC) } \\
\text { \& GP practice }\end{array}$ & $\begin{array}{l}\text { Disclosure criteria } \\
\text { not reported. } \\
\text { Individual semi } \\
\text { structured } \\
\text { interviews } \\
\text { (disclosure, } \\
\text { understanding of } \\
\text { illness \& treatment) }\end{array}$ & $\begin{array}{l}\text { Disclosure } \\
\text { status \& } \\
\text { grounded } \\
\text { theory } \\
\text { approach }\end{array}$ & $\begin{array}{l}29 \% \text { of children had been told about } \\
\text { their parents' HIV-positive status; } \\
33 \% \text { thought to have guessed \& } 38 \% \\
\text { believed to be unaware of their } \\
\text { parents'. Reasons for disclosure: the } \\
\text { child being HIV-positive, rest of the } \\
\text { family knowing or the parent } \\
\text { becoming very sick. Reasons for not } \\
\text { disclosing: believing the child to be } \\
\text { too young, not knowing how to } \\
\text { address the issue of HIV, or that it } \\
\text { would be too painful for the child. } \\
\text { Parents concerned other people } \\
\text { might find out their status or that } \\
\text { child would be stigmatised. Parents } \\
\text { described difficulties in addressing } \\
\text { issues of HIV \& sexual health with } \\
\text { their children, preference to leave } \\
\text { these topics for schools to address }\end{array}$ & $\begin{array}{l}\text { Botswan } \\
\text { a }\end{array}$ \\
\hline $\begin{array}{l}\text { Nelson and } \\
\text { While } 2002^{32}\end{array}$ & $\begin{array}{l}\text { Mixed } \\
\text { methods }\end{array}$ & 224 & $\begin{array}{l}144 \text { parents } \\
\text { (80 } \\
\text { patients, } 64 \\
\text { spouses); } \\
80 \text { children }\end{array}$ & $8-16$ & $\begin{array}{l}\text { Breast } \\
\text { cancer, } \\
\text { leukaemi } \\
\text { a, } \\
\text { gynaecol } \\
\text { ogical \& }\end{array}$ & $\begin{array}{l}\text { Cancer } \\
\text { centres }\end{array}$ & $\begin{array}{l}\text { Individual semi } \\
\text { structured } \\
\text { interviews. Child: } \\
\text { RCMAS, Adapted } \\
\text { SPQ. Self-Perception } \\
\text { Profile for Children, }\end{array}$ & $\begin{array}{l}\text { Communication } \\
\text { subscale on } \\
\text { SPQ, maternal } \\
\text { completion of } \\
\text { communication } \\
\text { measure, }\end{array}$ & $\begin{array}{l}\text { Family relationships not associated } \\
\text { with children's adjustment. Two main } \\
\text { risk factors for poor adjustment in } \\
\text { children were low self-esteem \& poor } \\
\text { adjustment in parent with cancer. } \\
\text { Communication about illness not }\end{array}$ & UK \\
\hline
\end{tabular}




\begin{tabular}{|c|c|c|c|c|c|c|c|c|c|c|}
\hline & & & & & $\begin{array}{l}\text { testicular } \\
\text { cancer }\end{array}$ & & $\begin{array}{l}\text { Social Support Scale } \\
\text { for Children. } \\
\text { Parent: Rutter Scale } \\
\text { A, HADS, MAC, } \\
\text { Malaise Inventory, } \\
\text { FES, adapted 8-item } \\
\text { communication } \\
\text { measure. } \\
\text { Teacher: Rutter } \\
\text { Scale B. }\end{array}$ & $\begin{array}{l}\text { content } \\
\text { analysis. }\end{array}$ & $\begin{array}{l}\text { associated with child adjustment so } \\
\text { not regarded as risk factor in this } \\
\text { study }\end{array}$ & \\
\hline $\begin{array}{l}\text { Niemela, } \\
\text { Paananen et } \\
\text { al. } 2012^{5}\end{array}$ & Quantitative & $\begin{array}{l}60,06 \\
9\end{array}$ & $\begin{array}{l}\text { Children in } \\
\text { Finland } \\
\text { born in } \\
1987\end{array}$ & $\begin{array}{l}\text { Retrospective } \\
21 \text { year } \\
\text { review of } \\
\text { children who } \\
\text { had a parent } \\
\text { suffering } \\
\text { from cancer }\end{array}$ & Cancer & $\begin{array}{l}\text { Data from } \\
\text { Finnish } \\
\text { Hospital } \\
\text { Discharge } \\
\text { Register }\end{array}$ & $\begin{array}{l}\text { Use of inpatient \& } \\
\text { outpatient } \\
\text { psychiatric services } \\
\text { recorded on Finnish } \\
\text { hospital Discharge } \\
\text { Register }\end{array}$ & Not measured & $\begin{array}{l}6.6 \% \text { of children born in Finland in } \\
1987 \text { had been affected by parental } \\
\text { cancer before the age of } 21 \text { years old. } \\
\text { These children, especially females, } \\
\text { had used psychiatric services in either } \\
\text { in or outpatient settings significantly } \\
\text { more often than their peers during } \\
\text { follow up time period. Increased } \\
\text { likelihood of psychiatric inpatient } \\
\text { care observed for male cohort } \\
\text { members when their father had } \\
\text { cancer }\end{array}$ & Finland \\
\hline $\begin{array}{l}\text { Ostrom, } \\
\text { Serovich et } \\
\text { al. } 2006^{64}\end{array}$ & $\begin{array}{l}\text { Mixed } \\
\text { methods }\end{array}$ & 45 & Mothers & $5-18(12.4)$ & HIV & $\begin{array}{l}\text { Longitudinal } \\
\text { study; HIV } \\
\text { clinics \& } \\
\text { service } \\
\text { organisations }\end{array}$ & $\begin{array}{l}\text { Disclosure classed } \\
\text { as: disclosed or non- } \\
\text { disclosed (maternal } \\
\text { rating). Disclosure } \\
\text { measured with a } \\
\text { social network } \\
\text { screening } \\
\text { questionnaire } \\
\text { (adapted ASSIS). } \\
\text { Reasons for } \\
\text { disclosure measured } \\
\text { using Likert scales. } \\
\text { HIV Stigma Scale }\end{array}$ & $\begin{array}{l}\text { Disclosure } \\
\text { status }\end{array}$ & $\begin{array}{l}95 \% \text { of women did not regret } \\
\text { disclosure, wanted to take a lead role } \\
\text { in disclosure to their child \& make } \\
\text { decision based on child's ability to } \\
\text { cope with information. Reasons } \\
\text { endorsed for disclosure: wanting } \\
\text { child to hear diagnosis from mother, } \\
\text { child had a right to know, wanting } \\
\text { child to understand mother's illness \& } \\
\text { preparing child for what might } \\
\text { happen. Reasons for non-disclosure: } \\
\text { wanting child to have a carefree, } \\
\text { worry-free childhood, wanting to } \\
\text { avoid child's anxiety about mother \& } \\
\text { protect child from reactions of } \\
\text { others. Mothers who experienced } \\
\text { stigma reported not disclosing to thei } \\
\text { r children for fear of child telling } \\
\text { others }\end{array}$ & USA \\
\hline $\begin{array}{l}\text { Palin, } \\
\text { Armistead et } \\
\text { al. } 2009^{34}\end{array}$ & Quantitative & 103 & Mothers & $11-16$ & HIV & $\begin{array}{l}\text { AIDS } \\
\text { organisations, } \\
\text { hospital, } \\
\text { radio }\end{array}$ & $\begin{array}{l}\text { Disclosure classed } \\
\text { as: disclosed or non- } \\
\text { disclosed (maternal } \\
\text { rating). Individual }\end{array}$ & $\begin{array}{l}\text { Disclosure } \\
\text { status }\end{array}$ & $\begin{array}{l}44 \% \text { of mothers had disclosed to their } \\
\text { child; of these mothers half had } \\
\text { disclosed within one year of diagnosis } \\
\& 70 \% \text { within } 2 \text { years of diagnosis. }\end{array}$ & $\begin{array}{l}\text { South } \\
\text { Africa }\end{array}$ \\
\hline
\end{tabular}




\begin{tabular}{|c|c|c|c|c|c|c|c|c|c|c|}
\hline & & & & & & $\begin{array}{l}\text { broadcasting } \\
\& \text { word of } \\
\text { mouth }\end{array}$ & $\begin{array}{l}\text { interviews (child } \\
\text { response to } \\
\text { disclosure, } \\
\text { disclosure } \\
\text { decisions), HESSI, } \\
\text { PSI, IBQ PCS, CBCL }\end{array}$ & & $\begin{array}{l}\text { Mothers most commonly endorsed } \\
\text { their child's reaction to disclosure as } \\
\text { sadness \& worry. } \\
\text { Disclosure to children significantly } \\
\text { predicated externalising but not } \\
\text { internalising behaviours, with more } \\
\text { externalising behaviour in the group } \\
\text { who had been disclosed to }\end{array}$ & \\
\hline $\begin{array}{l}\text { Paliokosta, } \\
\text { Diareme et } \\
\text { al. } 2009^{33}\end{array}$ & Quantitative & $\begin{array}{l}1 \\
57\end{array}$ & $\begin{array}{l}101 \\
\text { parents; } 56 \\
\text { children }\end{array}$ & $4-17$ & $\begin{array}{l}\text { Multiple } \\
\text { Sclerosis } \\
\text { (duration } \\
2 \\
\text { months- } \\
21 \text { years; } \\
\text { mean } \\
10.3 \\
\text { years) }\end{array}$ & $\begin{array}{l}\text { Hospital } \\
\text { neurology } \\
\text { clinics }\end{array}$ & $\begin{array}{l}\text { Disclosure classed } \\
\text { as: } 1 \text { no information } \\
\text { at all; } 2 \text { partial } \\
\text { information; } 3 \text { total } \\
\text { disclosure. } \\
\text { Individual semi } \\
\text { structured } \\
\text { interviews. } \\
\text { Parent: CBCL, BDI, } \\
\text { FAD. } \\
\text { Child: YSR, FAD. } \\
\text { Functional } \\
\text { impairment of } \\
\text { patient assessed by } \\
\text { doctor using } \\
\text { Karnofsky } \\
\text { performance Status } \\
\text { Scale }\end{array}$ & $\begin{array}{l}\text { Disclosure } \\
\text { status }\end{array}$ & $\begin{array}{l}\text { Fathers (both healthy \& affected) } \\
\text { with higher levels of depression had } \\
\text { children who had had more } \\
\text { information about parental illness. } \\
\text { Parental functional impairment was } \\
\text { not associated with communication } \\
\text { around illness. Children \& } \\
\text { adolescents who had 'partial } \\
\text { information' had higher scores in } \\
\text { social difficulties \& internalising } \\
\text { behaviours relative to the other two } \\
\text { groups. Children's self-rated scores of } \\
\text { social problems were significantly } \\
\text { higher for those who had had partial } \\
\text { information about the parental } \\
\text { illness. No correlations between } \\
\text { communication around illness \& } \\
\text { family functioning as assessed by } \\
\text { FAD. No relationship between } \\
\text { communication \& level of parental } \\
\text { education }\end{array}$ & Greece \\
\hline $\begin{array}{l}\text { Phillips and } \\
\text { Lewis } 2015^{57}\end{array}$ & Qualitative & 7 & Children & $11-15(13.6)$ & $\begin{array}{l}\text { Stage IV } \\
\text { cancer } \\
\text { (breast, } \\
\text { colorecta } \\
\mathrm{l}, \\
\text { carcinoid } \\
\text { ) }\end{array}$ & $\begin{array}{l}\text { Parents' } \\
\text { medical team }\end{array}$ & $\begin{array}{l}\text { Individual semi } \\
\text { structured } \\
\text { interviews } \\
\text { (experience of } \\
\text { parental cancer, } \\
\text { emotional and } \\
\text { informational } \\
\text { needs) }\end{array}$ & $\begin{array}{l}\text { Inductive } \\
\text { content analysis }\end{array}$ & $\begin{array}{l}\text { Individual variation in how much \& } \\
\text { how often wanted to talk about } \\
\text { parent's cancer. Difficult to initiate } \\
\text { these conversations \& sometimes } \\
\text { avoided the topic because it was } \\
\text { scary. Others found it helpful to talk } \\
\text { about cancer with parents }\end{array}$ & USA \\
\hline $\begin{array}{l}\text { Rosenheim } \\
\text { and Reicher } \\
1985^{29}\end{array}$ & Quantitative & 44 & Children & $6-16$ & $\begin{array}{l}\text { Cancer } \\
\text { (to } \\
\text { extent } \\
\text { that daily } \\
\text { functioni } \\
\text { ng was } \\
\text { impaired } \\
\text { \& }\end{array}$ & $\begin{array}{l}\text { Single cancer } \\
\text { centre }\end{array}$ & $\begin{array}{l}\text { Parental report of } \\
\text { disclosure classed } \\
\text { as: informed } \\
\text { (explicit naming of } \\
\text { cancer) or } \\
\text { uninformed. } \\
\text { Child: } 54 \text { item } \\
\text { Anxiety scale for }\end{array}$ & $\begin{array}{l}\text { Disclosure } \\
\text { status }\end{array}$ & $\begin{array}{l}\text { Anxiety of the informed group } \\
\text { significantly lower than the } \\
\text { uninformed group. }\end{array}$ & Israel \\
\hline
\end{tabular}




\begin{tabular}{|c|c|c|c|c|c|c|c|c|c|c|}
\hline & & & & & $\begin{array}{l}\text { evident } \\
\text { they } \\
\text { were ill; } \\
\text { Parents } \\
\text { undergoi } \\
\text { ng radio } \\
\text { or chemo } \\
\text { therapy) }\end{array}$ & & $\begin{array}{l}\text { children based on } \\
\text { McCandles } \\
\text { Costaneda \& } \\
\text { Palermo (1956) }\end{array}$ & & & \\
\hline $\begin{array}{l}\text { Sheehan, } \\
\text { Draucker et } \\
\text { al. 2014 }\end{array}$ & Qualitative & 56 & $\begin{array}{l}26 \\
\text { adolescents } \\
; 10 \text { ill } \\
\text { parents; } 20 \\
\text { well parents }\end{array}$ & $12-18(15)$ & $\begin{array}{l}\text { Cancer- } \\
17 \\
\text { ALS-1 } \\
\text { Multiple } \\
\text { Sclerosis } \\
-1 \\
\text { Pulmonar } \\
\text { y } \\
\text { disease-1 } \\
\text { vCJD-1 } \\
\text { No } \\
\text { response } \\
-1\end{array}$ & $\begin{array}{l}\text { Parents' } \\
\text { medical team } \\
\text { at single } \\
\text { hospice }\end{array}$ & $\begin{array}{l}\text { Individual } \\
\text { interviews } \\
\text { (experience of } \\
\text { disclosure) }\end{array}$ & $\begin{array}{l}\text { Constant } \\
\text { comparison } \\
\text { methods }\end{array}$ & $\begin{array}{l}\text { Outcomes of measured telling were } \\
\text { always good; parents proud of how } \\
\text { they had disclosed their illness/ } \\
\text { imminent death \& adolescents } \\
\text { satisfied at how disclosure occurred. } \\
\text { Participants reported it had } \\
\text { engendered trust within the family. } \\
\text { Outcomes of skirted telling were } \\
\text { generally positive; both parents \& } \\
\text { adolescents welcomed this approach } \\
\text { \& did not experience discord. } \\
\text { Outcomes of matter of fact telling } \\
\text { were neutral; not seen positive or } \\
\text { negative, rather that these } \\
\text { conversations 'occurred'. } \\
\text { Outcomes of inconsistent telling were } \\
\text { generally negative; adolescents } \\
\text { expressed anger \& felt they had } \\
\text { received too much or not enough } \\
\text { information. Parents were aware of } \\
\text { their adolescent's dissatisfaction }\end{array}$ & USA \\
\hline $\begin{array}{l}\text { Sipsma, Eloff } \\
\text { et al. } 2013^{36}\end{array}$ & Quantitative & 1018 & $\begin{array}{l}395 \text { HIV } \\
\text { positive } \\
\text { mothers; } \\
114 \text { HIV } \\
\text { negative } \\
\text { mothers; } \\
509 \\
\text { children }\end{array}$ & $6-10$ & HIV & Health clinics & $\begin{array}{l}\text { Disclosure classed } \\
\text { as: No disclosure; } \\
\text { partial; full } \\
\text { disclosure. } \\
\text { Parent: VABS, CBCL. } \\
\text { Child: CDI, RCMAS, } \\
\text { BEQI }\end{array}$ & $\begin{array}{l}\text { Disclosure } \\
\text { status }\end{array}$ & $\begin{array}{l}\text { 7.4\% of children had been informed } \\
\text { of their mother's HIV positive status } \\
\& 4.6 \% \text { partial disclosure. Children of } \\
\text { HIV positive mothers who had been } \\
\text { told their mother was sick had less } \\
\text { internalising \& externalising } \\
\text { behaviours \& improved skills of daily } \\
\text { living, compared to children who had } \\
\text { been told nothing. No psychological } \\
\text { benefit for those explicitly told about } \\
\text { HIV compared to the non-disclosure } \\
\text { group. Disease severity did not } \\
\text { moderate the effect of disclosure on } \\
\text { child outcomes. No differences on } \\
\text { child reported outcomes }\end{array}$ & $\begin{array}{l}\text { South } \\
\text { Africa }\end{array}$ \\
\hline
\end{tabular}




\begin{tabular}{|c|c|c|c|c|c|c|c|c|c|c|}
\hline $\begin{array}{l}\text { Thastum, } \\
\text { Johansen et } \\
\text { al. } 2008^{17}\end{array}$ & Qualitative & 36 & $\begin{array}{l}21 \text { children; } \\
15 \text { parents }\end{array}$ & $8-15(11)$ & $\begin{array}{l}\text { Cancer } \\
\text { (breast, } \\
\text { lung, } \\
\text { lymph, } \\
\text { cervical) } \\
\text { disease } \\
\text { duration } \\
2-153 \\
\text { months }\end{array}$ & $\begin{array}{l}\text { Parents' } \\
\text { hospital- } \\
\text { based } \\
\text { medical } \\
\text { team, GP \& } \\
\text { community } \\
\text { recruitment } \\
\text { (patient } \\
\text { organisations, } \\
\text { newspaper } \\
\text { advert) }\end{array}$ & $\begin{array}{l}\text { Individual } \\
\text { semi structured } \\
\text { interviews (child } \\
\text { knowledge of } \\
\text { parental illness \& } \\
\text { emotional } \\
\text { experience; parental } \\
\text { report of child's } \\
\text { knowledge) }\end{array}$ & $\begin{array}{l}\text { Phenomenologi } \\
\text { cal analysis }\end{array}$ & $\begin{array}{l}\text { Children felt important to have } \\
\text { knowledge about parent's illness. } \\
\text { Generally positive in their reports of } \\
\text { visiting hospital although some found } \\
\text { it frightening or boring. Parents who } \\
\text { had not immediately told their } \\
\text { children the diagnosis (to protect } \\
\text { their child or because of their own } \\
\text { feelings) regretted this decision as } \\
\text { they felt their child had reacted } \\
\text { negatively to the lack of information }\end{array}$ & $\begin{array}{l}\text { Denmar } \\
\mathrm{k}\end{array}$ \\
\hline $\begin{array}{l}\text { Thomas, } \\
\text { Nyamathi et } \\
\text { al. } 2009^{48}\end{array}$ & Qualitative & 60 & Mothers & $0-10$ & HIV/AIDS & $\begin{array}{l}\text { STD clinics, } \\
\text { HIV clinic \& } 2 \\
\text { maternity } \\
\text { hospitals }\end{array}$ & $\begin{array}{l}\text { Disclosure criteria } \\
\text { not reported. } \\
9 \text { focus groups using } \\
\text { semi structured } \\
\text { interview guide } \\
\text { based on } \\
\text { Comprehensive } \\
\text { Health Seeking \& } \\
\text { Coping paradigm } \\
\text { (issues relating to } \\
\text { disclosure to child } \\
\text { or family) }\end{array}$ & $\begin{array}{l}\text { Content } \\
\text { analysis }\end{array}$ & $\begin{array}{l}\text { Mothers feared disclosure; child may } \\
\text { discriminate against them, child's } \\
\text { studies adversely affected, or child } \\
\text { disclosed details to others. } 38 \% \text { of } \\
\text { women felt it best to delay disclosure } \\
\text { until children older \& able to } \\
\text { understand the impact of HIV on the } \\
\text { family. Suggestions that counsellor or } \\
\text { doctor could make or assist in } \\
\text { disclosure }\end{array}$ & India \\
\hline $\begin{array}{l}\text { Vallerand, } \\
\text { Hough et al. } \\
2005^{53}\end{array}$ & Qualitative & 54 & $\begin{array}{l}35 \text { HIV- } \\
\text { positive } \\
\text { mothers } \\
\text { who had } \\
\text { disclosed to } \\
\text { their } \\
\text { children; } 19 \\
\text { children }\end{array}$ & $10-18$ & HIV & $\begin{array}{l}\text { Longitudinal } \\
\text { study Living } \\
\text { with } \\
\text { HIV/AIDS: } \\
\text { Mother-child } \\
\text { Coping \& } \\
\text { Adjustment }\end{array}$ & $\begin{array}{l}\text { Individual semi } \\
\text { structured } \\
\text { interviews (issues } \\
\text { related to diagnosis } \\
\text { disclosure \& child } \\
\text { experience of } \\
\text { disclosure) }\end{array}$ & $\begin{array}{l}\text { Constant } \\
\text { comparative } \\
\text { method }\end{array}$ & $\begin{array}{l}\text { Disclosure encouraged open, honest } \\
\text { communication \& closer relationships } \\
\text { between mothers \& children. } \\
\text { Mothers disclosed when they felt } \\
\text { their child was developmentally } \\
\text { ready, that the information would } \\
\text { help protect their child from infection } \\
\text { themselves (through unprotected } \\
\text { sex) or when their health declined. } \\
\text { Reasons for not disclosing: fear of the } \\
\text { child not understanding \& fear of } \\
\text { stigma. Mothers identified some } \\
\text { negative effects of disclosure: child's } \\
\text { emotional reaction, fears \& } \\
\text { uncertainty. Mothers \& children also } \\
\text { raised fears about social ostracisation } \\
\text { following disclosure \& a need to } \\
\text { maintain secrecy around diagnosis }\end{array}$ & USA \\
\hline $\begin{array}{l}\text { Withell } \\
2009^{23}\end{array}$ & Qualitative & 10 & $\begin{array}{l}\text { Bereaved } \\
\text { adolescents }\end{array}$ & $13-19$ & HIV/AIDS & $\begin{array}{l}\text { Faith-based } \\
\text { HIV/AIDS } \\
\text { NGO }\end{array}$ & $\begin{array}{l}\text { Unstructured } \\
\text { interviews }\end{array}$ & $\begin{array}{l}\text { Descriptive } \\
\text { phenomenologi } \\
\text { cal approach }\end{array}$ & $\begin{array}{l}\text { Process of moving from a concealed } \\
\text { or disguised reality (no awareness } \\
\text { parent was seriously ill; awareness of }\end{array}$ & Uganda \\
\hline
\end{tabular}




\begin{tabular}{|c|c|c|c|c|c|c|c|c|c|c|}
\hline & & & & & & & & & $\begin{array}{l}\text { illness but believed to be treatable) } \\
\text { into discerned reality (guess parent } \\
\text { dying through observation or } \\
\text { intuition), with (for a few) a last } \\
\text { minute disclosed reality (disclosure } \\
\text { by dying parent). Where information } \\
\text { was lacking, children had to construct } \\
\text { their own reality of what was really } \\
\text { happening to their parent e.g. } \\
\text { attributing their parent's death to } \\
\text { witchcraft }\end{array}$ & \\
\hline $\begin{array}{l}\text { Wood, Chase } \\
\text { et al. 2006 }\end{array}$ & Qualitative & 97 & $\begin{array}{l}56 \text { orphans; } \\
41 \text { adults } \\
\text { (including } \\
\text { parents \& } \\
\text { members of } \\
\text { wider } \\
\text { community) }\end{array}$ & $7-22$ & HIV & 6 NGO sites & $\begin{array}{l}\text { Disclosure criteria } \\
\text { not reported. } \\
\text { Individual } \\
\text { interviews } \\
\text { (experience of } \\
\text { illness \& } \\
\text { bereavement) \& } \\
\text { observations, } \\
\text { participatory tools } \\
\text { including drawings } \\
\text { with younger } \\
\text { children }\end{array}$ & $\begin{array}{l}\text { Content } \\
\text { analysis }\end{array}$ & $\begin{array}{l}\text { Disclosure to children was rare, } \\
\text { although adolescents often strongly } \\
\text { suspected their parent's symptoms } \\
\text { were HIV-related. Orphaned } \\
\text { adolescents wanted direct } \\
\text { communication with adults about } \\
\text { illness \& described negative } \\
\text { emotional consequences of secrecy. } \\
\text { Adults largely mis-interpreted } \\
\text { children's withdrawal \& quietness as } \\
\text { a positive coping strategy }\end{array}$ & $\begin{array}{l}\text { Zimbab } \\
\text { we }\end{array}$ \\
\hline $\begin{array}{l}\text { Xu, Yan et al. } \\
2007^{62}\end{array}$ & Qualitative & 37 & $\begin{array}{l}16 \\
\text { caregivers; } \\
5 \text { key } \\
\text { informants; } \\
16 \text { children }\end{array}$ & $8-17(13)$ & $\begin{array}{l}\text { HIV/AIDS } \\
\text { (mean } \\
\text { time } \\
\text { since } \\
\text { diagnosis } \\
\text { for non- } \\
\text { orphans } \\
15 \\
\text { months) }\end{array}$ & $\begin{array}{l}\text { Local } \\
\text { community } \\
\text { HCPs working } \\
\text { with people } \\
\text { with HIV }\end{array}$ & $\begin{array}{l}\text { Disclosure criteria } \\
\text { not reported. } \\
\text { Individual semi } \\
\text { structured } \\
\text { interviews }\end{array}$ & $\begin{array}{l}\text { Constant } \\
\text { comparative } \\
\text { method }\end{array}$ & $\begin{array}{l}3 \text { of the } 16 \text { children knew their } \\
\text { parents had HIV; disclosure prompted } \\
\text { by the child seeing some evidence of } \\
\text { parental illness. Most caregivers \& } \\
\text { community informants suggested not } \\
\text { telling children to protect them from } \\
\text { unpleasant events including } \\
\text { discrimination or stigmatisation \& } \\
\text { psychological distress. }\end{array}$ & China \\
\hline $\begin{array}{l}\text { Zhao, Li et al. } \\
2015^{9}\end{array}$ & Quantitative & 626 & Children & $\begin{array}{l}6-17 \\
(10.59)\end{array}$ & HIV & $\begin{array}{l}\text { Community } \\
\text { recruitment }\end{array}$ & $\begin{array}{l}\text { Disclosure classed } \\
\text { as: disclosed (told } \\
\text { by parents about } \\
\text { illness in general or } \\
\text { HIV specifically) or } \\
\text { nondisclosed. } \\
\text { children. Survey } \\
\text { (awareness of } \\
\text { parental illness \& } \\
\text { disclosure). } \\
\text { CES-DC, CLS, PSS, } \\
\text { RSES, SACAA, }\end{array}$ & $\begin{array}{l}\text { Disclosure } \\
\text { status \& } \\
\text { content analysis }\end{array}$ & $\begin{array}{l}31 \% \text { of fathers \& } 39 \% \text { of mothers had } \\
\text { told their children about their illness. } \\
95 \% \text { of children who had not been } \\
\text { disclosed to by parents were aware of } \\
\text { their parent's HIV status from other } \\
\text { people or from their own } \\
\text { observations. }\end{array}$ & China \\
\hline
\end{tabular}




\begin{tabular}{|c|c|c|c|c|c|c|c|c|c|c|}
\hline & & & & & & & $\begin{array}{l}\text { Enacted stigma, } \\
\text { Children Future } \\
\text { Expectation Scale, } \\
\text { Hopefulness about } \\
\text { future, Perceived } \\
\text { control over the } \\
\text { future }\end{array}$ & & & \\
\hline $\begin{array}{l}\text { Zhou, Zhang } \\
\text { et al. } 2013^{55}\end{array}$ & Qualitative & 39 & Parents & $\begin{array}{l}24 \%<8 \text { years; } \\
24 \% 8-14 \\
\text { years. } 20 \% \\
15-21 \text { years; } \\
28 \%>21 \\
\text { years. }\end{array}$ & HIV & HIV clinics & $\begin{array}{l}\text { Disclosure classed } \\
\text { as: disclosure and } \\
\text { non-disclosure. } \\
\text { Open ended } \\
\text { interviews (reasons } \\
\text { for disclosure, } \\
\text { impact of disclosure } \\
\text { on child, future } \\
\text { disclosure } \\
\text { intentions) }\end{array}$ & $\begin{array}{l}\text { Content } \\
\text { analysis }\end{array}$ & $\begin{array}{l}77 \% \text { of parents had not disclosed HIV } \\
\text { status to children. Parents who } \\
\text { disclosed were older \& more likely to } \\
\text { disclose to their adult children (mean } \\
\text { age of children who had been } \\
\text { disclosed to was } 27 \text { years, range } 11- \\
52 \text { years). Reasons for disclosure: } \\
\text { need for emotional \& financial } \\
\text { support, to prevent their child } \\
\text { becoming infected, in response to } \\
\text { their child's suspicions. Reasons for } \\
\text { non-disclosure: child too young to } \\
\text { understand, fear of being stigmatised, } \\
\text { fear of being rejected by child, fear of } \\
\text { psychological burden to child. 50\% of } \\
\text { non-disclosing participants did not } \\
\text { plan to disclose in the future. }\end{array}$ & China \\
\hline
\end{tabular}

ASSIS - Arizona Social Support Interview Schedule

BDI - Beck Depression Inventory

BEQI - Baron Emotional Quotient Inventory (Youth version)

BSI - Brief Symptom Inventory

$\mathrm{CBCL}$ - Child Behaviour Checklist

CDI - Children Depression Inventory

CES-DC - Center for Epidemiological Studies Depression Scale for Children

$\mathrm{CHQ}-\mathrm{MH}-$ Mental health subscale of the Child Health Questionnaire

CLS - Children's Loneliness Scale

DDM - Devaluation-Discrimination Measure

DISC: Diagnostic Interview Schedule for Children

ED - Emergency Department

FAD - Family Assessment Device

FPRQ - Family Peer Relations Questionnaire

FES - Family Environment Scale

GHQ - General Health Questionnaire 
HADS: Hospital Anxiety and Depression Scale

HCP - Health Care Professional

$\mathrm{HDI}$ - Hamilton Depression inventory

HESSI - Household Economic \& Social Status index

HIV SS - HIV Stigma scale

HSC - Hopelessness scale for Children

IBQ - Interaction Behaviour Questionnaire

ICU-intensive Care unit

(C)-IES - (Child) Impact of Events Scale

IPA - Interpretative Phenomenological Analysis

MAC: Mental Adjustment to Cancer scale

MASC: Multidimensional Anxiety Scale

MOHS - Medical Outcomes Health Survey (SF8)

OSSS - Oslo Social Support Scale

PACS - Parent-Adolescent Communication Scale

$\mathrm{PBI}$ - Parental Bonding Instrument

PCS - Parenting Convergence Scale

POMS - Profile of Mood States

PPI: Parent Perception Inventory

PRS - Perceived Risk Scale

PSI - Physical Symptoms Inventory

PSS - Perceived Stigma Scale

PTSS - posttraumatic stress symptoms

RCMAS- Revised Children's Manifest Anxiety Scale

RSES - Rosenberg Self Esteem Scale

SMFQ-short: Short Mood \& Feelings Questionnaire

SMS - HIV-related Stigma Management Scale

SPQ - Sibling Perception Questionnaire

SACAA - Stigma Against Children Affected by AIDS

STAI-CH - State Trait Anxiety for Children

VABS - Vinel \& Adaptive Behaviour Scales

YSR- Youth self-report form 
Table 2: Studies evaluating clinical interventions for families when a parent has a life threatening condition

\begin{tabular}{|c|c|c|c|c|c|c|c|c|c|c|c|}
\hline Author & $\begin{array}{l}\text { Size of } \\
\text { study } \\
\text { (n) }\end{array}$ & $\begin{array}{l}\text { Type of } \\
\text { participants }\end{array}$ & $\begin{array}{l}\text { Child } \\
\text { age } \\
\text { range in } \\
\text { years } \\
\text { (mean) } \\
\end{array}$ & $\begin{array}{l}\text { Parental } \\
\text { diagnosis }\end{array}$ & $\begin{array}{l}\text { Method of } \\
\text { recruitment }\end{array}$ & Method & Description of intervention & Measures & $\begin{array}{l}\text { How was } \\
\text { communication } \\
\text { addressed during } \\
\text { intervention? }\end{array}$ & Results & Location \\
\hline $\begin{array}{l}\text { Betancourt, Ng } \\
\text { et al. 201743; } \\
\text { Chaudhury, } \\
\text { Kirk et al. } \\
2016^{44}\end{array}$ & 293 & $\begin{array}{l}170 \text { children; } \\
123 \\
\text { caregivers }\end{array}$ & $\begin{array}{l}7-17 \\
(11.76)\end{array}$ & HIV & $\begin{array}{l}\text { Parent's } \\
\text { medical team }\end{array}$ & RCT & $\begin{array}{l}\text { Modular, home-based } \\
\text { (Family Support } \\
\text { Intervention, FSI) to } \\
\text { promote parent-child } \\
\text { relationships. Aim: to elicit } \\
\text { participants' current } \\
\text { challenges \& apply family's } \\
\text { strengths \& strategies } \\
\text { successfully used in past. } \\
\text { Control group: treatment as } \\
\text { usual }\end{array}$ & $\begin{array}{l}\text { Adapted \& validated } \\
\text { for Rwandan context. } \\
\text { Child: CES-DC; conduct } \\
\text { problems scale; } \\
\text { WHODAS-Child, Family } \\
\text { Connectedness, } \\
\text { Parenting scale } \\
\text { adapted from PARQ. } \\
\text { Parent: Family } \\
\text { Connectedness, } \\
\text { parenting scale } \\
\text { adapted from PARQ }\end{array}$ & $\begin{array}{l}\text { Intervention aimed } \\
\text { to improve } \\
\text { communication \& } \\
\text { understanding }\end{array}$ & $\begin{array}{l}\text { Children who received FSI } \\
\text { had fewer symptoms of } \\
\text { depression (parental \& self- } \\
\text { report) at } 3 \text { month follow } \\
\text { up. No differences between } \\
\text { groups on outcomes of child } \\
\text { behaviour, child functional } \\
\text { impairment, family } \\
\text { connectedness or parenting. } \\
\text { After HIV disclosure children } \\
\text { reported lower levels of } \\
\text { parenting \& family unity } \\
\text { scores; these differences } \\
\text { were not seen at } 3 \text { month } \\
\text { follow up }\end{array}$ & Rwanda \\
\hline $\begin{array}{l}\text { Christ, Raveis } \\
\text { et al. } 2005^{40}\end{array}$ & $\begin{array}{l}184 \\
\text { (plus a } \\
\text { compari } \\
\text { son } \\
\text { group of } \\
556 \text { non } \\
\text { bereave } \\
d \\
\text { children } \\
\text { ) }\end{array}$ & 184 families & $7-17$ & $\begin{array}{l}\text { Cancer; } \\
\text { advanced } \\
\text { disease } \\
\text { with } \\
\text { estimated } \\
\text { survival } \\
\text { time of } 6 \\
\text { months or } \\
\text { less }\end{array}$ & $\begin{array}{l}\text { Parent's } \\
\text { medical team }\end{array}$ & RCT & $\begin{array}{l}12 \text { month parent-guidance } \\
\text { intervention of } 6 \text { or more } \\
\text { sessions; } \\
\text { psychoeducational; } \\
\text { enhancing surviving } \\
\text { parent's ability to provide } \\
\text { care \& support for children; } \\
\text { provide environment where } \\
\text { child felt able to express } \\
\text { feelings about loss \& } \\
\text { maintain consistency \& } \\
\text { stability in child's } \\
\text { environment. Support for } \\
\text { parents through their own } \\
\text { grief work in order to } \\
\text { enhance their capacity to } \\
\text { function effectively. } \\
\text { Individual interview of child; } \\
\text { perceptions of family } \\
\text { communication which then } \\
\text { informed parent } \\
\text { intervention. } \\
\text { Control group: telephone } \\
\text { monitoring 4-8 weekly; } \\
\text { maintain contact with well } \\
\text { parent \& facilitate referral } \\
\text { to appropriate resources. } \\
\text { Initiated during parent's }\end{array}$ & $\begin{array}{l}\text { Child: CDI; STAI-ch; } \\
\text { PPM; IDRCM. } \\
\text { Parent: CBCL }\end{array}$ & $\begin{array}{l}\text { Current approaches } \\
\text { to communication } \\
\text { within family \& } \\
\text { terminal illness } \\
\text { discussed Often } \\
\text { included } \\
\text { encouraging } \\
\text { extensive } \\
\text { preparation of } \\
\text { children for } \\
\text { progression of } \\
\text { illness, reviewing } \\
\text { specific words \& } \\
\text { concepts for talking } \\
\text { about illness, } \\
\text { treatment \& death, } \\
\text { developmental } \\
\text { issues \& impact of } \\
\text { parental feelings on } \\
\text { their ability to } \\
\text { understand or meet } \\
\text { child' needs }\end{array}$ & $\begin{array}{l}\text { No statistically significant } \\
\text { differences between groups } \\
\text { on measures of child anxiety } \\
\text { or depression, but children } \\
\text { of parents in experimental } \\
\text { arm a greater decline in } \\
\text { scores over time (from } \\
\text { initiation of intervention to } \\
6 \text { months post } \\
\text { bereavement). } \\
\text { Children of parents in } \\
\text { experimental arm rated } \\
\text { their parent's overall } \\
\text { competence \& general } \\
\text { communication as } \\
\text { significantly better during \& } \\
\text { after the intervention } \\
\text { compared to control }\end{array}$ & USA \\
\hline
\end{tabular}




\begin{tabular}{|c|c|c|c|c|c|c|c|c|c|c|c|}
\hline & & & & & & & $\begin{array}{l}\text { terminal cancer \& } \\
\text { continuing until } 6 \text { months } \\
\text { after death }\end{array}$ & & & & \\
\hline $\begin{array}{l}\text { Greening } \\
1992^{67}\end{array}$ & 51 & $\begin{array}{l}30 \text { children; } \\
21 \text { parents }\end{array}$ & $4-8$ & $\begin{array}{l}\text { Parents } \\
\text { with } \\
\text { recurrent } \\
\text { or } \\
\text { metastatic } \\
\text { disease, } \\
\text { receiving } \\
\text { radiothera } \\
\text { py, chemo } \\
\text { therapy or } \\
\text { both }\end{array}$ & $\begin{array}{l}\text { Parent's } \\
\text { medical team }\end{array}$ & $\begin{array}{l}\text { Evaluati } \\
\text { on of } \\
\text { group } \\
\text { by } \\
\text { parent } \\
\text { particip } \\
\text { ants }\end{array}$ & $\begin{array}{l}\text { Monthly meetings } 1.5 \\
\text { hours; parallel children's \& } \\
\text { parents' groups. }\end{array}$ & None used & $\begin{array}{l}\text { Themes of children's } \\
\text { group included } \\
\text { information and } \\
\text { practical aspects of } \\
\text { cancer, including } \\
\text { visiting the hospital } \\
\text { \& information about } \\
\text { treatment \& } \\
\text { equipment. Session } \\
\text { on feelings \& } \\
\text { emotional } \\
\text { expression. Parallel, } \\
\text { facilitated, parent } \\
\text { sessions included } \\
\text { discussion about } \\
\text { what to tell children } \\
\text { about parental } \\
\text { illness \& } \\
\text { developmental } \\
\text { understanding }\end{array}$ & $\begin{array}{l}\text { Parental feedback very } \\
\text { positive. Parents indicated } \\
\text { they would not attend a } \\
\text { support group for } \\
\text { themselves, but were highly } \\
\text { motivated to engage in any } \\
\text { support available for their } \\
\text { child. Parents attended } \\
\text { group due to concerns } \\
\text { about their child's future \& } \\
\text { a desire for information \& } \\
\text { reassurance from } \\
\text { professionals. Parents did } \\
\text { not expect to benefit } \\
\text { themselves, but found it a } \\
\text { valuable experience }\end{array}$ & USA \\
\hline $\begin{array}{l}\text { Lewis, Brandt } \\
\text { et al. 201537 }\end{array}$ & 352 & $\begin{array}{l}176 \text { mothers; } \\
176 \text { children }\end{array}$ & $8-12$ & $\begin{array}{l}\text { Diagnosed } \\
\text { within } 6 \\
\text { months } \\
\text { with Stage } \\
\text { 0-III breast } \\
\text { cancer }\end{array}$ & $\begin{array}{l}\text { Parents' } \\
\text { medical team } \\
\text { in } 6 \text { US } \\
\text { states; } \\
\text { community } \\
\text { cancer } \\
\text { centres \& } \\
\text { self-referral }\end{array}$ & RCT & $\begin{array}{l}5 \text { fullly scripted patient } \\
\text { education counselling } \\
\text { sessions delivered at } 2 \text { week } \\
\text { intervals to mother; } \\
\text { interactive booklet about } \\
\text { breast cancer read by } \\
\text { mother to child; mother's } \\
\text { workbook containing } \\
\text { didactic text, in-session \& } \\
\text { at-home assignments } \\
\text { completed by mother \& } \\
\text { child; child completed } \\
\text { activity booklet about how } \\
\text { child deals with stress. } \\
\text { Access to patient educator } \\
\text { via pager if required. } \\
\text { Control group: mothers } \\
\text { received printed booklet } \\
\text { focussing on ways to } \\
\text { support child about breast } \\
\text { cancer; short (<10 mins) } \\
\text { follow up call to review key } \\
\text { points in booklet }\end{array}$ & $\begin{array}{l}\text { Mother: CESDS; STAl; } \\
\text { CSES; FPRS; PSC. } \\
\text { Child: CBCL; RCMAS; } \\
\text { CDI (maternal \& child } \\
\text { report) }\end{array}$ & $\begin{array}{l}\text { Developing mother's } \\
\text { listening skills; } \\
\text { understanding } \\
\text { child's experience as } \\
\text { distinct from her } \\
\text { own (strategies to } \\
\text { prevent emotionally } \\
\text { flooding child); } \\
\text { attending to child's } \\
\text { thoughts, feelings \& } \\
\text { concerns; strategies } \\
\text { to support child who } \\
\text { may be reluctant to } \\
\text { share their feelings }\end{array}$ & $\begin{array}{l}\text { Significant improvements in } \\
\text { depression, parenting skills } \\
\text { \& child behavioural- } \\
\text { emotional adjustment and } \\
\text { depression relative to } \\
\text { controls at } 2 \text { month follow } \\
\text { up. At } 1 \text { year post } \\
\text { intervention, children of } \\
\text { mothers in the experimental } \\
\text { arm remained significantly } \\
\text { less depressed compared to } \\
\text { controls (child \& parent } \\
\text { report). } \\
\text { Intervention did not affect } \\
\text { parenting self-efficacy or } \\
\text { maternal anxiety }\end{array}$ & USA \\
\hline $\begin{array}{l}\text { Murphy, } \\
\text { Armistead et } \\
\text { al. 201138 }\end{array}$ & 160 & $\begin{array}{l}80 \text { mothers; } \\
80 \text { children }\end{array}$ & $\begin{array}{l}6-12 \\
(8.7)\end{array}$ & HIV & $\begin{array}{l}\text { HIV/AIDS } \\
\text { service } \\
\text { organisations }\end{array}$ & RCT & $\begin{array}{l}\text { Standard care plus } 3 \\
\text { sessions; child } \\
\text { development, pros \& cons } \\
\text { of disclosure, improving } \\
\text { mother-child } \\
\text { communication, }\end{array}$ & $\begin{array}{l}\text { Mother: DSE; FRQ; } \\
\text { PACS; PSI; RMHI; MOS } \\
\text { SF-36; FC from FFS } \\
\text { Child: CDI, PHCSCS; } \\
\text { IPPA }\end{array}$ & $\begin{array}{l}\text { Intervention } \\
\text { targeted at } \\
\text { enhancing familial } \\
\text { communication \& } \\
\text { parenting skills } \\
\text { specifically around } \\
\end{array}$ & $\begin{array}{l}33 \% \text { of intervention group \& } \\
7 \% \text { of control group } \\
\text { disclosed during course of } \\
\text { study. Mothers in } \\
\text { intervention group had } \\
\text { increased disclosure self- }\end{array}$ & USA \\
\hline
\end{tabular}




\begin{tabular}{|c|c|c|c|c|c|c|c|c|c|c|c|}
\hline & & & & & & & $\begin{array}{l}\text { behavioural practice for } \\
\text { disclosure. } \\
\text { Control group: Standard } \\
\text { care }\end{array}$ & & $\begin{array}{l}\text { disclosure, } \\
\text { increasing readiness } \\
\text { to disclose } \\
\text { /disclosure }\end{array}$ & $\begin{array}{l}\text { efficacy, increased parent- } \\
\text { child communication \& } \\
\text { improved maternal } \\
\text { emotional functioning. } \\
\text { Children of mothers in the } \\
\text { intervention group showed } \\
\text { reductions in depression \& } \\
\text { anxiety \& increases in } \\
\text { happiness (regardless of } \\
\text { disclosure status). } \\
\text { Intervention helpful for } \\
\text { mental health indicators, } \\
\text { even if mothers did not } \\
\text { disclose } \\
\end{array}$ & \\
\hline $\begin{array}{l}\text { O'Malley, } \\
\text { Beima-Sofie et } \\
\text { al. } 2015^{69}\end{array}$ & 81 & $\begin{array}{l}46 \text { caregivers; } \\
35 \text { HCPs }\end{array}$ & $7-15$ & HIV & HIV clinics & $\begin{array}{l}\text { Evaluati } \\
\text { on of } \\
\text { interven } \\
\text { tion }\end{array}$ & $\begin{array}{l}\text { Book with cartoons to } \\
\text { facilitate caregivers \& HCPs } \\
\text { gradual disclose. Includes } \\
\text { information on medication } \\
\text { and HIV }\end{array}$ & $\begin{array}{l}\text { Semi structured } \\
\text { interviews \& } \\
\text { questionnaires } \\
\text { regarding HCPs' } \\
\text { confidence in } \\
\text { managing HIV } \\
\text { disclosure \& } \\
\text { experience of } \\
\text { implementing } \\
\text { intervention }\end{array}$ & $\begin{array}{l}\text { Disclosure of HIV } \\
\text { book sharing }\end{array}$ & $\begin{array}{l}\text { Caregivers \& HCPs found } \\
\text { book helpful in disclosing } \\
\text { the child's HIV status \& } \\
\text { increasing their skills to } \\
\text { facilitate their child's } \\
\text { medication adherence. } \\
\text { HCPs reported book } \\
\text { reduced caregivers' } \\
\text { reluctance to disclose }\end{array}$ & Namibia \\
\hline $\begin{array}{l}\text { Rochat, } \\
\text { Mkwanazi et } \\
\text { al. 201377 }\end{array}$ & 48 & $\begin{array}{l}24 \text { mothers; } \\
24 \text { children }\end{array}$ & $6-9(7.8)$ & HIV & $\begin{array}{l}\text { Re-enrolled } \\
\text { from } \\
\text { previous } \\
\text { study } \\
\text { conducted in } \\
\text { the Africa } \\
\text { Centre }\end{array}$ & $\begin{array}{l}\text { Pilot } \\
\text { study to } \\
\text { establis } \\
\mathrm{h} \\
\text { feasibilit } \\
\mathrm{y} \text { and } \\
\text { accepta } \\
\text { bility of } \\
\text { the } \\
\text { Amagug } \\
u \\
\text { interven } \\
\text { tion }\end{array}$ & $\begin{array}{l}6 \text { session training } \\
\text { intervention led by } \\
\text { community worker for } \\
\text { mothers \& their children; } \\
\text { written materials \& games } \\
\text { to prepare for \& support } \\
\text { maternal HIV disclosure to } \\
\text { uninfected children; clinic } \\
\text { and HCP training on child } \\
\text { friendly clinical spaces }\end{array}$ & $\begin{array}{l}\text { Qualitative measures } \\
\text { of participants' } \\
\text { perceptions of } \\
\text { intervention, self- } \\
\text { reported maternal } \\
\text { health prior disclosure } \\
\text { experience, disclosure } \\
\text { level \& impact on } \\
\text { family. Disclosure } \\
\text { classed as Full } \\
\text { disclosure using the } \\
\text { words HIV; } \\
\text { Partial disclosure } \\
\text { excludes the words HIV } \\
\text { \& substitute virus or } \\
\text { illness }\end{array}$ & $\begin{array}{l}\text { Amagugu } \\
\text { Intervention: } \\
\text { Communication } \\
\text { using materials such } \\
\text { as board games, } \\
\text { playing cards, } \\
\text { storybooks assisted } \\
\text { parents in talking } \\
\text { about HIV in a } \\
\text { structured and clear } \\
\text { way }\end{array}$ & $\begin{array}{l}\text { All mothers chose to } \\
\text { disclose something about } \\
\text { their illlness; half achieving } \\
\text { full disclosure. Mothers' } \\
\text { concerns about disclosure } \\
\text { included child's emotional } \\
\text { distress, risk of child } \\
\text { disclosing to other people \& } \\
\text { managing child's questions } \\
\text { about HIV. Children's } \\
\text { reaction to disclosure } \\
\text { (maternal report): } 14 \\
\text { children calm \& confident, } 8 \\
\text { confused \& 2 distressed or } \\
\text { fearful. Materials were seen } \\
\text { as culturally sensitive \& } \\
\text { helpful by community } \\
\text { workers and stakeholders. }\end{array}$ & South Africa \\
\hline $\begin{array}{l}\text { Rochat, } \\
\text { Arteche et al. } \\
2014^{52} \text { and } \\
2015^{46}\end{array}$ & 562 & $\begin{array}{l}281 \text { mothers; } \\
281 \text { children }\end{array}$ & $6-10$ & HIV & $\begin{array}{l}\text { Re-enrolled } \\
\text { from } \\
\text { previous } \\
\text { study } \\
\text { conducted in } \\
\text { the Africa } \\
\text { Centre }\end{array}$ & $\begin{array}{l}\text { Uncontr } \\
\text { olled } \\
\text { pre \& } \\
\text { post } \\
\text { interven } \\
\text { tion } \\
\text { evaluati } \\
\text { ve of } \\
\text { the } \\
\text { Amagug } \\
\end{array}$ & $\begin{array}{l}6 \text { sessions at home; printed } \\
\text { materials \& child-friendly } \\
\text { activities to prepare for \& } \\
\text { support maternal HIV } \\
\text { disclosure to uninfected } \\
\text { children }\end{array}$ & $\begin{array}{l}\text { Mother: took child to } \\
\text { clinic visit, completed } \\
\text { child care plan, } \\
\text { discussed care plan } \\
\text { with child, legal } \\
\text { guardian appointed } \\
\text { and timing, GHQ, PSI, } \\
\text { CBCL. } \\
\text { Process evaluation } \\
\text { data on maternal and } \\
\end{array}$ & $\begin{array}{l}\text { Amagugu } \\
\text { intervention }\end{array}$ & $\begin{array}{l}60 \% \text { of mothers 'fully } \\
\text { disclosed' \& } 40 \% \text { 'partially } \\
\text { disclosed' their HIV status to } \\
\text { their child. Mothers who } \\
\text { perceived their health to be } \\
\text { excellent were less likely to } \\
\text { fully disclose compared to } \\
\text { those considering their } \\
\text { health to be poorer. More } \\
\text { likely to fully disclose if in }\end{array}$ & South Africa \\
\hline
\end{tabular}




\begin{tabular}{|c|c|c|c|c|c|c|c|c|c|c|c|}
\hline & & & & & & $\begin{array}{l}\text { u } \\
\text { Interven } \\
\text { tion. }\end{array}$ & & $\begin{array}{l}\text { child experiences of } \\
\text { intervention. } \\
\text { Disclosure classed as } \\
\text { Full disclosure using } \\
\text { the words HIV; } \\
\text { Partial disclosure } \\
\text { excludes the words HIV } \\
\& \text { substitute virus or } \\
\text { illness; No disclosure. }\end{array}$ & & $\begin{array}{l}\text { current partnership. Most } \\
\text { children reacted calmly to } \\
\text { full or partial diagnosis } \\
\text { (maternal report). Children } \\
\text { whose mothers fully } \\
\text { disclosed were significantly } \\
\text { more likely to react } \\
\text { surprised \& less likely to } \\
\text { react confused. Mothers } \\
\text { much more likely to report } \\
\text { their child's reaction to the } \\
\text { diagnosis as 'emotional'. } \\
\text { Compared to partial } \\
\text { disclosure, full disclosure } \\
\text { associated with more } \\
\text { children asking questions } \\
\text { about maternal death. } \\
\text { Maternal reported } \\
\text { psychological distress \& } \\
\text { parenting stress decreased } \\
\text { following intervention. } \\
\text { Reduction in child } \\
\text { emotional \& behaviour } \\
\text { difficulties (maternal } \\
\text { report). Reductions in } \\
\text { scores were not moderated } \\
\text { by the level of disclosure } \\
\text { (full/partial). }\end{array}$ & \\
\hline $\begin{array}{l}\text { Rochat, } \\
\text { Mitchell et al. } \\
2017^{72}\end{array}$ & 562 & $\begin{array}{l}281 \text { mothers; } \\
281 \text { children }\end{array}$ & $6-10$ & HIV & $\begin{array}{l}\text { Secondary } \\
\text { analysis of } \\
\text { evaluation } \\
\text { data in } \\
\text { Rochat et al } \\
2014 \text { and } \\
2015\end{array}$ & $\begin{array}{l}\text { Mixed } \\
\text { method } \\
\mathrm{s}\end{array}$ & $\begin{array}{l}\text { See Rochat et al } 2014 \text { and } \\
2015\end{array}$ & $\begin{array}{l}\text { GHQ and parenting } \\
\text { stress PSI; Child mental } \\
\text { health CBCL } \\
\text { Maternal reported } \\
\text { data on: } \\
\text { Most and least } \\
\text { enjoyable parts of } \\
\text { intervention; question } \\
\text { children asked post } \\
\text { disclosure; child } \\
\text { emotional reactions to } \\
\text { disclosure; child IQ } \\
\text { (Ravens) } \\
\text { Full disclosure using } \\
\text { the words HIV; } \\
\text { Partial disclosure using } \\
\text { the words virus or } \\
\text { illness. }\end{array}$ & $\begin{array}{l}\text { Amagugu } \\
\text { Intervention }\end{array}$ & $\begin{array}{l}\text { 61/281 children asked death } \\
\text { related questions; most } \\
\text { concerned about the threat } \\
\text { of death, their mother's } \\
\text { survival \& prior family } \\
\text { deaths. Children more likely } \\
\text { to ask a death related } \\
\text { question if their initial } \\
\text { response had been fearful \& } \\
\text { their mother had regular } \\
\text { income. Full disclosure led } \\
\text { to increased odds of } \\
\text { questions about death. } \\
\text { Children who discussed the } \\
\text { possibility of death with } \\
\text { parents showed improved } \\
\text { scores in post intervention } \\
\text { evaluation (when } \\
\text { controlling for baseline } \\
\text { CBCL). Discussion of death } \\
\text { did not increase } \\
\text { psychological problems. } \\
\text { Evidence that many children } \\
\text { were aware of the effects of }\end{array}$ & South Africa \\
\hline
\end{tabular}




\begin{tabular}{|c|c|c|c|c|c|c|c|c|c|c|c|}
\hline & & & & & & & & & & $\begin{array}{l}\text { HIV on family, } \\
\text { hospitalisation, and deaths. }\end{array}$ & \\
\hline $\begin{array}{l}\text { Rochat, Stein } \\
\text { et al. 201742 }\end{array}$ & 928 & $\begin{array}{l}464 \text { mothers; } \\
464 \text { children }\end{array}$ & $6-10$ & HIV & $\begin{array}{l}\text { Primary } \\
\text { healthcare } \\
\text { facilities }\end{array}$ & RCT & $\begin{array}{l}\text { Intervention group: } 6 \\
\text { sessions at home; printed } \\
\text { materials \& child-friendly } \\
\text { activities to prepare for \& } \\
\text { support maternal HIV } \\
\text { disclosure to uninfected } \\
\text { children. Control group: } \\
\text { Enhanced standard of care } \\
\text { of one clinic based } \\
\text { counselling session. }\end{array}$ & $\begin{array}{l}\text { Mother: PHQ-9, PSI, } \\
\text { GAD-7, FAD, CBCL, took } \\
\text { child to clinic visit, } \\
\text { completed child care } \\
\text { plan, discussed care } \\
\text { plan with child, legal } \\
\text { guardian appointed } \\
\text { and timing. } \\
\text { Disclosure classed as: } \\
\text { Full disclosure using } \\
\text { the words HIV; } \\
\text { Partial disclosure } \\
\text { excludes the words HIV } \\
\text { \& substitute virus or } \\
\text { illness; } \\
\text { No disclosure. }\end{array}$ & $\begin{array}{l}\text { Amagugu } \\
\text { Intervention }\end{array}$ & $\begin{array}{l}\text { Higher rates of disclosure } \\
\text { (partial or full) in } \\
\text { intervention group (n=204 } \\
[87 \%]) \text { compared to control } \\
\text { (n=128 [56\%]. } \\
\text { Full disclosure was also } \\
\text { more common in } \\
\text { intervention group (n=150 } \\
[64 \%]) \text { compared to control } \\
\text { (n=98 [43\%]) and time to } \\
\text { disclosure was significantly } \\
\text { shorter in the intervention } \\
\text { group. } \\
\text { Intervention participants } \\
\text { were more likely to take } \\
\text { their child to visit the clinic, } \\
\text { develop care plan and } \\
\text { appoint a legal guardian. } \\
\text { No significant differences in } \\
\text { mental health in either } \\
\text { parents or children between } \\
\text { groups. Significant } \\
\text { improvements in the } \\
\text { parent-child relationship in } \\
\text { the intervention group. }\end{array}$ & South Africa \\
\hline $\begin{array}{l}\text { Rotheram- } \\
\text { Borus, Lee et } \\
\text { al. } 2001^{41}\end{array}$ & 719 & $\begin{array}{l}307 \text { parents; } \\
412 \\
\text { adolescents }\end{array}$ & $\begin{array}{l}11-18 \\
(14.8)\end{array}$ & HIV & $\begin{array}{l}\text { HIV /AIDS } \\
\text { services } \\
\text { database }\end{array}$ & $\begin{array}{l}\text { RCT } \\
\text { compari } \\
\text { ng } \\
\text { group } \\
\text { interven } \\
\text { tion } \\
\text { with } \\
\text { standar } \\
\text { d care }\end{array}$ & $\begin{array}{l}24 \text { sessions focused on } \\
\text { emotional reactions to } \\
\text { illness, stigma, disclosure, } \\
\text { conflict resolution \& future } \\
\text { planning. Attended by } \\
\text { parents \& adolescents } \\
\text { (parallel groups) }\end{array}$ & $\begin{array}{l}\text { Parent: BSI, Coping } \\
\text { with Illness } \\
\text { Questionnaire (5 } \\
\text { subscales), custody } \\
\text { plan parameters, count } \\
\text { of multiple problem } \\
\text { behaviours. } \\
\text { Adolescent: BSI, count } \\
\text { of multiple problem } \\
\text { behaviours, conduct } \\
\text { problems, RSES }\end{array}$ & $\begin{array}{l}\text { Intervention group } \\
\text { modules }\end{array}$ & $\begin{array}{l}\text { Intervention group had } \\
\text { significantly lower levels of } \\
\text { emotional distress \& family } \\
\text { related stressors, fewer } \\
\text { behavioural problems, } \\
\text { higher self-esteem at } 24 \\
\text { months follow up compared } \\
\text { to control group. Parents } \\
\text { reported lower levels of } \\
\text { emotional distress \& fewer } \\
\text { problem behaviours. High } \\
\text { levels of disclosure (both at } \\
\text { baseline \& } 24 \text { month follow } \\
\text { up), similar for both groups. }\end{array}$ & USA \\
\hline $\begin{array}{l}\text { Thastum, } \\
\text { Munch-Hansen } \\
\text { et al. 200639 }\end{array}$ & 75 & $\begin{array}{l}24 \text { mothers; } \\
17 \text { fathers; } 34 \\
\text { children }\end{array}$ & $\begin{array}{l}8-15 \\
(11.4)\end{array}$ & Cancer & $\begin{array}{l}\text { Somatically } \\
\text { III Parents } \\
\text { (COSIP) study }\end{array}$ & $\begin{array}{l}\text { Evaluati } \\
\text { on of } \\
\text { short } \\
\text { term } \\
\text { prevent } \\
\text { ative } \\
\text { counsell } \\
\text { ing } \\
\text { project }\end{array}$ & $\begin{array}{l}5-6 \text { sessions (mean } 4.75 \\
\text { sessions per family) focused } \\
\text { on illness-related problems. } \\
\text { Attended by family } \\
\text { members, usually at home. } \\
\text { Children also offered group } \\
\text { counselling with other } \\
\text { children participating in } \\
\text { project. }\end{array}$ & $\begin{array}{l}\text { Parent: BDI; FAD } \\
\text { Child: BYI, IPPA, } \\
\text { QMHRQoLCA. } \\
\text { Evaluation of } \\
\text { intervention by } \\
\text { parents, children and } \\
\text { therapists through } \\
\text { semi structured } \\
\text { interviews about } \\
\text { experience of } \\
\end{array}$ & $\begin{array}{l}\text { Aims of intervention: } \\
\text { facilitate open } \\
\text { communication } \\
\text { about illness, } \\
\text { increase parental } \\
\text { emotional } \\
\text { availability, support } \\
\text { parents in age- } \\
\text { appropriate } \\
\text { communication of } \\
\end{array}$ & $\begin{array}{l}\text { Significant decrease in } \\
\text { depression for mothers \& } \\
\text { increase in family } \\
\text { functioning (Communication } \\
\text { \& Affective Responsiveness } \\
\text { subscales) for parents after } \\
\text { the intervention. } \\
\text { Significant decrease in } \\
\text { depression scores for }\end{array}$ & Denmark \\
\hline
\end{tabular}




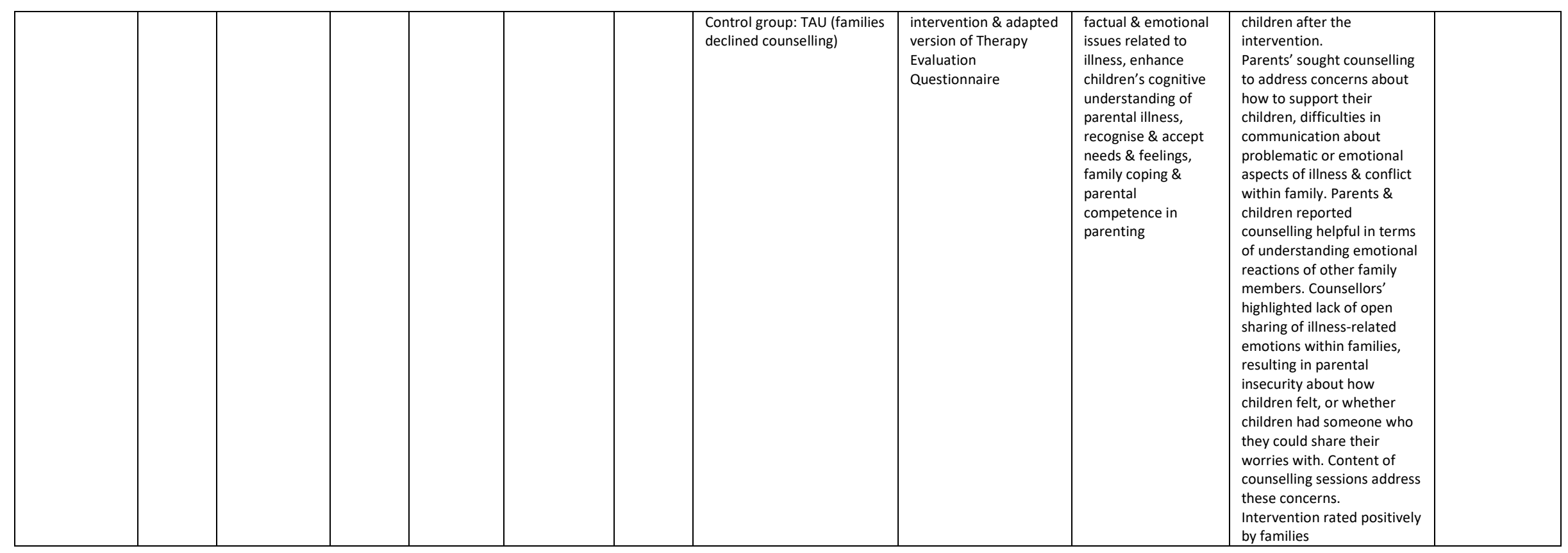

BDI: Beck Depression Inventory

BYI: Beck Youth Inventory

CDI: Children's Depression Inventory

CES-DS: Center for Epidemiological Studies Depression Scale

CSES: Cancer Self-Efficacy Scale

DSE: Disclosure Self-efficacy

EORTCQoLQ: European Organisation for Research \& Treatment of Cancer Quality of Life Questionnaire

FAD: McMaster Family Assessment Device

FC from FFS: Family Cohesion subscale from Family Functioning Scale

FPRS: Family-Peer Relationship Scale

FRQ: Family Routines Questionnaire

GCQ: General Communication Questionnaire

GHQ: General Health Questionnaire

IAS: Illness Attitudes Scale

IBQ: Interaction Behaviour Questionnaire 
IDRCM: Illness \& Death-related Communication Measure

IPPA: Inventory of Parent \& Peer Attachment

IQoLCA: Inventory for Quality of Life in Children \& Adolescents

MOS SF-36: Medical Outcome Study Short Form 36

PACS: Parent-Adolescent Communication Scale

PARQ: Parental Acceptance-Rejection Questionnaire

PHCSCS: Piers-Harris Children's Self Concept Scale

PSC: Parenting Skills Checklist

PSI: Parenting Stress Index

PPM: Perception of Parenting Measure

RCMAS: Revised Children's Manifest Anxiety Scale

RMHI: Rand Mental Health Inventory

RSES - Rosenberg Self Esteem Scale

SC-90: Symptoms Checklist-90 for adults

SC: Sense of Coherence

SDQ: Strengths \& Difficulties Questionnaire

STAI: Spielberger State-Trait Anxiety Inventory

STAI-ch: State-Trait Anxiety Inventory for Children

QMHRQoLCA: Questionnaire for Measuring Health-related Quality of Life in Children \& Adolescents

WHODAS-Child: World Health Organisation Disability Assessment Schedule for Children 


\section{References}

1. Weaver KE, Rowland JH, Alfano CM, McNeel TS. Parental cancer and the family: a population-based estimate of the number of US cancer survivors residing with their minor children. Cancer 2010; 116(18): 4395-401.

2. WHO. 2018. http://www.who.int/mediacentre/factsheets/fs297/en/ (accessed 12 April 2018).

3. WHO. 2005. http://www.who.int/hiv/mediacentre/news55/en/ (accessed 12 April 2018).

4. UNAIDS. http://www.unaids.org/en/resources/fact-sheet (accessed 5 April 2018).

5. Niemela M, Paananen R, Hakko H, Merikukka M, Gissler M, Rasanen S. The prevalence of children affected by parental cancer and their use of specialized psychiatric services: the 1987 Finnish Birth Cohort study. Int J Cancer 2012; 131(9): 2117-25.

6. Clark SJ, Kahn K, Houle B, et al. Young children's probability of dying before and after their mother's death: a rural South African population-based surveillance study. PLoS Med 2013; 10(3): e1001409.

7. Fallowfield $L$, Jenkins V. Communicating sad, bad, and difficult news in medicine. Lancet 2004; 363(9405): 312-9.

8. Levetown M, American Academy of Pediatrics Committee on B. Communicating with children and families: from everyday interactions to skill in conveying distressing information. Pediatrics 2008; 121(5): e1441-60.

9. Zhao J, Li X, Qiao S, Zhao G, Zhang L, Stanton B. Parental HIV disclosure: from perspectives of children affected by HIV in Henan, China. AIDS Care 2015; 27(4): 416-23.

10. Nam SL, Fielding K, Avalos A, Gaolathe T, Dickinson D, Geissler PW. Discussing matters of sexual health with children: what issues relating to disclosure of parental HIV status reveal. AIDS Care 2009; 21(3): 389-95.

11. Wood K, Chase E, Aggleton P. 'Telling the truth is the best thing': teenage orphans' experiences of parental AIDS-related illness and bereavement in Zimbabwe. Soc Sci Med 2006; 63(7): 1923-33.

12. Murphy DA. HIV-positive mothers' disclosure of their serostatus to their young children: a review. Clin Child Psychol Psychiatry 2008; 13(1): 105-22.

13. Beale EA, Sivesind D, Bruera E. Parents dying of cancer and their children. Palliat Support Care 2004; 2(4): 387-93.

14. Forrest G, Plumb C, Ziebland S, Stein A. Breast cancer in the family--children's perceptions of their mother's cancer and its initial treatment: qualitative study. BMJ 2006; 332(7548): 998-1003.

15. Bylund-Grenklo T, Kreicbergs $U$, Uggla $C$, et al. Teenagers want to be told when a parent's death is near: A nationwide study of cancer-bereaved youths' opinions and experiences. Acta Oncol 2015; 54(6): 944-50.

16. Ellis J, Dowrick C, Lloyd-Williams M. The long-term impact of early parental death: lessons from a narrative study. $J$ R Soc Med 2013; 106(2): 57-67.

17. Thastum M, Johansen MB, Gubba L, Olesen LB, Romer G. Coping, social relations, and communication: A qualitative exploratory study of children of parents with cancer. Clinical Child Psychology and Psychiatry 2008; 13(1): 123-38.

18. Christ GH, Siegel K, Freund B, et al. Impact of parental terminal cancer on latency-age children. Am J Orthopsychiatry 1993; 63(3): 417-25.

19. Christ GH, Christ AE. Current approaches to helping children cope with a parent's terminal illness. CA Cancer J Clin 2006; 56(4): 197-212.

20. Su YH, Ryan-Wenger NA. Children's adjustment to parental cancer - A theoretical model development. Cancer Nurs 2007; 30(5): 362-81.

21. Forrest G, Plumb C, Ziebland S, Stein A. Breast cancer in young families: a qualitative interview study of fathers and their role and communication with their children following the diagnosis of maternal breast cancer. Psychooncology 2009; 18(1): 96-103. 
22. Kristjanson LJ, Chalmers KI, Woodgate R. Information and support needs of adolescent children of women with breast cancer. Oncol Nurs Forum 2004; 31(1): 111-9.

23. Withell B. The prebereavement psychological needs of AIDS-affected adolescents in Uganda. Int J Palliat Nurs 2009; 15(3): 128-33.

24. Kennedy VL, Lloyd-Williams M. Information and communication when a parent has advanced cancer. J Affect Disord 2009; 114(1-3): 149-55.

25. Harris ES. Adolescent bereavement following the death of a parent: An exploratory study. Child Psychiatry and Human Development 1991; 21(4): 267-81.

26. Murphy DA, Steers WN, Dello Stritto ME. Maternal disclosure of mothers' HIV serostatus to their young children. J Fam Psychol 2001; 15(3): 441-50.

27. Harris CA, Zakowski SG. Comparisons of distress in adolescents of cancer patients and controls. Psycho-Oncology 2003; 12(2): 173-82.

28. Edwards L, Watson M, James-Roberts IS, et al. Adolescent's stress responses and psychological functioning when a parent has early breast cancer. Psycho-Oncology 2008; 17(10): 1039-47.

29. Rosenheim E, Reicher R. Informing children about a parent's terminal illness. J Child Psychol Psychiatry 1985; 26(6): 995-8.

30. Huizinga GA, Visser A, van der Graaf WT, et al. Stress response symptoms in adolescent and young adult children of parents diagnosed with cancer. Eur J Cancer 2005; 41(2): 288-95.

31. Huizinga GA, Visser A, van der Graaf WT, Hoekstra HJ, Hoekstra-Weebers JE. The quality of communication between parents and adolescent children in the case of parental cancer. Ann Oncol 2005; 16(12): 1956-61.

32. Nelson E, While D. Children's adjustment during the first year of a parent's cancer diagnosis. Journal of Psychosocial Oncology 2002; 20(1): 15-36.

33. Paliokosta $E$, Diareme $S$, Kolaitis $G$, et al. Breaking bad news: communication around parental multiple sclerosis with children. Fam Syst Health 2009; 27(1): 64-76.

34. Palin FL, Armistead L, Clayton A, et al. Disclosure of maternal HIV-infection in South Africa: description and relationship to child functioning. AIDS Behav 2009; 13(6): 1241-52.

35. Lee MB, Rotheram-Borus MJ. Parents' disclosure of HIV to their children. AIDS 2002; 16(16): 2201-7.

36. Sipsma $\mathrm{H}$, Eloff I, Makin J, et al. Behavior and psychological functioning of young children of HIV-positive mothers in South Africa. AIDS Care 2013; 25(6): 721-5.

37. Lewis FM, Brandt PA, Cochrane BB, et al. The Enhancing Connections Program: a six-state randomized clinical trial of a cancer parenting program. J Consult Clin Psychol 2015; 83(1): 12-23. 38. Murphy DA, Armistead L, Marelich WD, Payne DL, Herbeck DM. Pilot trial of a disclosure intervention for HIV+ mothers: The TRACK program. Journal of Consulting and Clinical Psychology 2011; 79(2): 203-14.

39. Thastum M, Munch-Hansen A, Wiell A, Romer G. Evaluation of a Focused Short-term Preventive Counselling Project for Families with a Parent with Cancer. Clinical Child Psychology and Psychiatry 2006; 11(4): 529-42.

40. Christ GH, Raveis VH, Seigel K, Karus D, Christ AE. Evaluation of a preventive intervention for bereaved children. J Soc Work End Life Palliat Care 2005; 1(3): 57-81.

41. Rotheram-Borus MJ, Lee MB, Gwadz M, Draimin B. An intervention for parents with AIDS and their adolescent children. Am J Public Health 2001; 91(8): 1294-302.

42. Rochat TJ, Stein A, Cortina-Borja M, Tanser F, Bland RM. The Amagugu intervention for disclosure of maternal HIV to uninfected primary school-aged children in South Africa: a randomised controlled trial. Lancet HIV 2017; 4(12): e566-e76.

43. Betancourt TS, Ng LC, Kirk CM, et al. Family-based promotion of mental health in children affected by HIV: a pilot randomized controlled trial. J Child Psychol Psychiatry 2017; 58(8): 922-30. 
44. Chaudhury S, Kirk CM, Ingabire C, et al. HIV Status Disclosure through Family-Based Intervention Supports Parenting and Child Mental Health in Rwanda. Front Public Health 2016; 4: 138.

45. Barnes J, Kroll L, Burke O, Lee J, Jones A, Stein A. Qualitative interview study of communication between parents and children about maternal breast cancer. BMJ 2000; 321(7259): 479-82.

46. Rochat TJ, Arteche AX, Stein A, Mitchell J, Bland RM. Maternal and child psychological outcomes of HIV disclosure to young children in rural South Africa: the Amagugu intervention. AIDS 2015; 29 Suppl 1: S67-79.

47. Armistead L, Tannenbaum L, Forehand R, Morse E, Morse P. Disclosing HIV status: are mothers telling their children? J Pediatr Psychol 2001; 26(1): 11-20.

48. Thomas B, Nyamathi A, Swaminathan S. Impact of HIV/AIDS on mothers in Southern India: A qualitative study. AIDS and Behavior 2009; 13(5): 989-96.

49. Barnes J, Kroll L, Lee J, Burke O, Jones A, Stein A. Factors predicting communication about the diagnosis of maternal breast cancer to children. J Psychosom Res 2002; 52(4): 209-14.

50. Giesbers J, de Leeuw IMV, van Zuuren FJ, Kleverlaan N, van der Linden MH. Coping with parental cancer: A web-based peer support in children. Psycho-Oncology 2010; 19: 887-92.

51. Letteney S, LaPorte HH. Deconstructing stigma: perceptions of HIV-seropositive mothers and their disclosure to children. Soc Work Health Care 2004; 38(3): 105-23.

52. Rochat TJ, Arteche AX, Stein A, Mkwanazi N, Bland RM. Maternal HIV disclosure to young HIV-uninfected children: an evaluation of a family-centred intervention in South Africa. AIDS 2014; 28 Suppl 3: S331-41.

53. Vallerand $\mathrm{AH}$, Hough $\mathrm{E}$, Pittiglio L, Marvicsin D. The process of disclosing HIV serostatus between HIV-positive mothers and their HIV-negative children. AIDS Patient Care STDS 2005; 19(2): 100-9.

54. Qiao S, Li X, Stanton B. Disclosure of parental HIV infection to children: a systematic review of global literature. AIDS Behav 2013; 17(1): 369-89.

55. Zhou Y, Zhang L, Li X, Kaljee L. Do Chinese parents with HIV tell their children the truth? A qualitative preliminary study of parental HIV disclosure in China. Child Care Health Dev 2013; 39(6): 816-24.

56. Murphy DA, Roberts KJ, Hoffman D. Regrets and Advice from Mothers who have Disclosed their HIV + Serostatus to their Young Children. Journal of Child and Family Studies 2003; 12(3): 30718.

57. Phillips F, Lewis FM. The adolescent's experience when a parent has advanced cancer: A qualitative inquiry. Palliative Medicine 2015; 29(9): 851-8.

58. Maynard A, Patterson P, McDonald FE, Stevens G. What is helpful to adolescents who have a parent diagnosed with cancer? J Psychosoc Oncol 2013; 31(6): 675-97.

59. Helseth S, Ulfsaet N. Parenting experiences during cancer. J Adv Nurs 2005; 52(1): 38-46.

60. Krauel K, Simon A, Krause-Hebecker N, Czimbalmos A, Bottomley A, Flechtner H. When a parent has cancer: challenges to patients, their families and health providers. Expert Rev Pharmacoecon Outcomes Res 2012; 12(6): 795-808.

61. Patenaude AF, Kupst MJ. Psychosocial functioning in pediatric cancer. J Pediatr Psychol 2005; 30(1): 9-27.

62. Xu T, Yan Z, Rou K, et al. Disclosure of parental HIV/AIDS to children in rural China. Vulnerable Children and Youth Studies 2007; 2(2): 100-5.

63. De Baets AJ, Sifovo S, Parsons R, Pazvakavambwa IE. HIV disclosure and discussions about grief with Shona children: a comparison between health care workers and community members in Eastern Zimbabwe. Social Science \& Medicine 2008; 66(2): 479-91.

64. Ostrom RA, Serovich JM, Lim JY, Mason TL. The role of stigma in reasons for HIV disclosure and non-disclosure to children. AIDS Care 2006; 18(1): 60-5. 
65. Ernst JC, Beierlein V, Romer G, Moller B, Koch U, Bergelt C. Use and need for psychosocial support in cancer patients: a population-based sample of patients with minor children. Cancer 2013; 119(12): 2333-41.

66. Inhestern L, Haller AC, Wlodarczyk O, Bergelt C. Psychosocial Interventions for Families with Parental Cancer and Barriers and Facilitators to Implementation and Use - A Systematic Review. PLoS ONE 2016; 11(6): e0156967.

67. Greening K. The "Bear Essentials" program: Helping young children and their families cope when a parent has cancer. Journal of Psychosocial Oncology 1992; 10(1): 47-61.

68. Mkwanazi NB, Rochat TJ, Imrie J, Bland RM. Disclosure of maternal HIV status to children: considerations for research and practice in sub-Saharan Africa. Future Virol 2012; 7(12): 1159-82.

69. O'Malley G, Beima-Sofie K, Feris L, et al. "If I take my medicine, I will be strong: " evaluation of a pediatric HIV disclosure intervention in Namibia. J Acquir Immune Defic Syndr 2015; 68(1): e1-7. 70. Amery J, Downing J, Cunningham C. In: Amery J, ed. Children's Palliative Care in Africa. New York, USA: Oxford Univeristy Press; 2009: 289-304.

71. Sheehan DK, Draucker CB, Christ GH, Mayo MM, Heim K, Parish S. Telling adolescents a parent is dying. Journal of Palliative Medicine 2014; 17(5): 512-20.

72. Rochat TJ, Mitchell J, Lubbe AM, Stein A, Tomlinson M, Bland RM. Communication about HIV and death: Maternal reports of primary school-aged children's questions after maternal HIV disclosure in rural South Africa. Soc Sci Med 2017; 172: 124-34.

73. Chowns G. 'Until it ends, you never know....': Attending to the voice of adolescents who are facing the likely death of a parent. Bereavement Care 2013; 32(1): 23-30.

74. Ellis SJ, Wakefield CE, Antill G, Burns M, Patterson P. Supporting children facing a parent's cancer diagnosis: a systematic review of children's psychosocial needs and existing interventions. Eur J Cancer Care (Engl) 2016; 26(1): 1-22.

75. Davey MP, Tubbs CY, Kissil K, Nino A. 'We are survivors too': African-American youths' experiences of coping with parental breast cancer. Psycho-Oncology 2011; 20(1): 77-87.

76. Bugge KE, Helseth S, Darbyshire P. Parents' experiences of a Family Support Program when a parent has incurable cancer. J Clin Nurs 2009; 18(24): 3480-8.

77. Rochat TJ, Mkwanazi N, Bland R. Maternal HIV disclosure to HIV-uninfected children in rural South Africa: a pilot study of a family-based intervention. BMC Public Health 2013; 13: 147.

78. Mkwanazi NB, Rochat TJ, Bland RM. The Amagugu intervention: a qualitative investigation into maternal experiences and perspectives of a maternal HIV disclosure support intervention in rural South Africa. Health Policy Plan 2017; 32(9): 1231-40.

79. UNICEF. Convention on the Rights of the Child. 1989.

80. Shields L, Zhou H, Pratt J, Taylor M, Hunter J, Pascoe E. Family-centred care for hospitalised children aged 0-12 years. Cochrane Database Syst Rev 2012; 10: CD004811. 